\title{
EXPORTING LIQUIDITY: \\ BRANCH BANKING AND FINANCIAL INTEGRATION
}

\author{
Erik Gilje \\ Elena Loutskina \\ Philip E. Strahan \\ Working Paper 19403 \\ http://www.nber.org/papers/w19403
NATIONAL BUREAU OF ECONOMIC RESEARCH
1050 Massachusetts Avenue
Cambridge, MA 02138 \\ September 2013
}

We thank seminar participants at University of Amsterdam, ESSEC, University of Houston, INSEAD, University of Michigan, University of Virginia, University of Rotterdam, and Tilburg University. The views expressed herein are those of the authors and do not necessarily reflect the views of the National Bureau of Economic Research.

NBER working papers are circulated for discussion and comment purposes. They have not been peerreviewed or been subject to the review by the NBER Board of Directors that accompanies official NBER publications.

(C) 2013 by Erik Gilje, Elena Loutskina, and Philip E. Strahan. All rights reserved. Short sections of text, not to exceed two paragraphs, may be quoted without explicit permission provided that full credit, including $\odot$ notice, is given to the source. 
Exporting Liquidity: Branch Banking and Financial Integration

Erik Gilje, Elena Loutskina, and Philip E. Strahan

NBER Working Paper No. 19403

September 2013

JEL No. G21

\section{$\underline{\text { ABSTRACT }}$}

Using exogenous deposit windfalls from oil and natural gas shale discoveries, we demonstrate that bank branch networks help integrate U.S. lending markets. We find that banks exposed to shale booms increase their mortgage lending in non-boom counties by $0.93 \%$ per $1 \%$ increase in deposits. This effect is present only in markets where banks have branches and is strongest for mortgages that are hard to securitize. Our findings suggest that contracting frictions limit the ability of arm's length finance to integrate credit markets fully. Branch networks continue to play an important role in financial integration, despite the development of securitization markets.

\section{Erik Gilje}

The Wharton School University of Pennsylvania

3620 Locust Walk, Suite 2400

Philadelphia, PA 19104

gilje@wharton.upenn.edu

Elena Loutskina

Darden School

University of Virginia

100 Darden Blvd

Charlottesville VA 22903

Loutskinae@darden.virginia.edu
Philip E. Strahan

Carroll School of Management

324B Fulton Hall

Boston College

Chestnut Hill, MA 02467

and NBER

philip.strahan@bc.edu 


\section{INTRODUCTION}

Over the past thirty years the banking system in the U.S. has gone through a significant transformation, relying more on capital markets and direct finance in funding loans and less on bank deposits. The U.S. mortgage market has been at the forefront of this transformation, with 52\% of loans in 2011 financed by securitization markets, up from $12 \%$ in $1980 .{ }^{1}$ Moreover, improvements in information technology have facilitated bank lending well outside of branchbased geographical domains (Petersen and Rajan, 2002). These changes have integrated local credit markets by allowing capital to flow more freely across markets. The greater role of external capital markets should have diminished the value of bank branch networks for lending. But despite these changes, the extent and density of bank offices and branches has continued to grow, from 63,200 (about 5 per bank) in 1990 to 89,800 (about 14 per bank) in 2012. ${ }^{2}$

In this paper, we study the role of branch networks in integrating segments of credit markets where arm’s length financing, such as securitization, has been limited by agency and information frictions. We exploit exogenous shocks to the supply of local bank deposits and detailed loan-level data to trace how these liquidity shocks propagate across markets. We document that banks increase their lending by $0.93 \%$ per $1 \%$ increase in deposits. This effect, however, is evident only in markets where banks have a branch presence. Moreover, the effect is concentrated in loans that are subject to more contracting frictions, and therefore are harder to fund from external markets (e.g., through securitization). These results provide 'smoking gun' evidence that branch networks allow lenders to mitigate contracting frictions, and play an important role in financial integration.

\footnotetext{
${ }^{1}$ These statistics refer to the whole mortgage market, including mortgages for home purchase, home equity lines, as well as mortgage re-financings.

${ }^{2}$ See http://www2.fdic.gov/hsob/HSOBRpt.asp.
} 
Why might local deposit supply affect credit? Absent contracting frictions, changes in deposits should not affect loan supply; banks would already make all profitable loans. Lenders could finance the marginal loan either by borrowing in capital markets, selling the loan to other investors, or securitizing the loan. In such a world, home buyers themselves would be able to borrow anywhere, thus making the local pool of savings irrelevant for credit conditions. Bank branches would exist solely to provide convenience to depositors.

Contracting frictions, however, may constrain arm's length finance, either because lenders have better information than investors or because incentives for lenders to monitor diminish if a loan is sold (e.g., Gorton and Pennacchi, 1995, Holmstrom and Tirole, 1997, Keys et al, 2010). Adverse selection, for example, limits securitization for loans made by lenders with clear informational advantages over potential secondary market buyers (Loutskina and Strahan, 2011). If a branch presence lowers the cost of information production or allows better monitoring of distressed properties, then local deposits could be important for credit supply. In line with this argument, we evaluate whether local deposit shocks increase the availability of credit across all of a lender's markets. We then test whether branch presence plays an important role in the propagation of these shocks due to reducing information frictions. Finally, we test whether deposit windfalls have their greatest effect on loans that are harder to finance through external capital markets due to contracting frictions (e.g., home equity loans that are subordinated).

We exploit an exogenous positive shock to bank deposits caused by mineral royalty payments to local landowners for the development of shale gas by oil and gas companies. These payments increase deposits at banks with branches in shale-boom counties (Gilje, 2011 and Plosser, 2011). Prospecting and development for shale has resulted in 327 banks receiving 
deposit windfalls in different years between 2003 and 2010 as new discoveries were made. Consistent with the unexpected nature of these discoveries, we find no evidence that banks with a greater need of funds to support loan growth establish new branches in counties experiencing shale booms.

Armed with this exogenous deposit shock, we evaluate its effects on mortgage lending in counties connected to shale booms via bank branch networks. We focus on lending growth outside of shale-boom counties. Thus, our sample selection alleviates concerns that lending is being driven by the direct effects of shale discoveries on credit demand. Exploring mortgage lending is advantageous for two reasons. First, these loans have a clear geographical dimension pinned down by the property location, which is not possible for other types of loans. Second, the rich dataset allows us to saturate the model with county*year fixed effects, thus removing all potentially confounding demand effects. Conceptually, our regressions compare mortgage growth rates for two otherwise similar banks for properties located in the same county-year, one bank having branches in a shale-boom county (and thus getting a positive external liquidity shock) and the other having no branches in shale-boom counties.

In our first set of tests, we estimate the elasticity of mortgage lending with respect to deposits in an IV setting. We find that a one percent increase in deposits results in $0.93 \%$ increase in mortgage originations. More importantly, the estimated elasticity of lending growth to deposit growth is much larger for retained mortgages (2.27\%), where banks' liquidity should matter. We find no effect of deposit growth on sold mortgages, as these are funded by national capital markets (rather than a bank's deposits). These results suggest that banks export deposits to non-booming markets and increase credit supply rather than merely retain more loans. 
We then evaluate how the effect of the shocks differs with market and mortgage characteristics. We simplify the empirical set-up by estimating reduced form models, which allow us to add interaction effects that would be difficult to estimate in the IV setting. Consistent with the idea that a physical presence reduces contracting frictions (e.g., Berger et al, 2005), we find that banks experiencing deposit windfalls increase mortgage lending only in outlying (nonboom) counties where they have branches. They do not lend more in areas where they have no branch presence and thus have no advantage over the other sources of financing (e.g. securitization).

To further support this notion, we document that deposit windfalls expand lending more in segments subject to greater contracting frictions, which are less likely to be securitized, such as home equity lines (sold or securitized $4.5 \%$ of the time) and home-purchase mortgage (sold or securitized $46 \%$ of the time), as opposed to mortgage re-financings (sold or securitized $65 \%$ of the time). Arguably, the deposit windfalls could be financing bad loans, as managers waste the unexpected funds on pet projects (Jensen, 1986). While this agency based explanation is hard to rule out completely, we provide evidence inconsistent with it.

Our findings contribute to three strands of the literature. First, the results extend research on the financial integration of U.S. markets and help explain why large benefits followed deregulation. ${ }^{3}$ Two mechanisms, potentially working in parallel, can explain why the removal of restrictions on banks' ability to expand across geographical markets improved economic outcomes: tougher competition and improved capital mobility. There is abundant evidence that

\footnotetext{
${ }^{3}$ The intrastate branching deregulation led to faster growth of the state economies (Jayaratne and Strahan (1996)) and lower growth volatility (Morgan, Rime and Strahan (2004)). Such deregulation came with better quality lending (Jayaratne and Strahan, 1996), more entrepreneurship and a greater share of small establishments (Black and Strahan 2002; Cetorelli and Strahan, 2006, Kerr and Nanda, 2009), lower income inequality, less labor-market discrimination and weaker labor unions (Black and Strahan, 2001; Beck et al, 2010; Levkov, 2012).
} 
increases in competition post-deregulation led to more efficient banking (Stiroh and Strahan, 2003), lowered the cost of capital for non-financial firms (Rice and Strahan, 2010) and contributed to better allocation of resources (Jayaratne and Strahan, 1996). There is much less evidence, however, about deregulation's effect on capital mobility. In this paper, we show that branch networks contribute to the integration of local credit markets. Thus, the increasing scope and density of bank branch networks that followed deregulation potentially allows savings in areas with a relative dearth of good projects to finance investment in areas with higher-return projects.

Second, extant research evaluates whether close proximity between borrowers and lenders lowers the cost of information production and monitoring. Breakthroughs in information technology allowed for larger distances between borrowers and lenders (Petersen and Rajan, 2002). However, local lenders still extend more credit to riskier borrowers than distant lenders: loan rates tend to decline with the distance between borrower and lender (Degryse and Ongena, 2005; Agrawal and Hauswald, 2010); more opaque (smaller) borrowers tend to establish enduring relationships with their local (small) banks; and larger, more transparent firms tend to borrow from larger (not so local) financial intermediaries (e.g., Berger et al, 2005). In mortgage finance, locally concentrated lenders focus on soft information intensive segments of the mortgage market (Loutskina and Strahan, 2011) and have an advantage in screening and monitoring riskier borrowers (Cortes, 2011). We contribute to this literature by documenting that even in the most developed, integrated, and technologically advanced lending market (the U.S. mortgage market), local branching networks - and by extension local knowledge - remain important for segments of the credit markets subject to contracting frictions. 
Finally, we offer a novel identification strategy to test whether and how bank liquidity shocks affect credit supply. ${ }^{4}$ The extant literature offers different empirical designs to avoid confounding effects of credit demand or unobserved productivity shocks. Some studies exploit cross-sectional differences in bank on-balance-sheet lending responses to aggregate liquidity shocks from monetary policy (e.g., Gertler and Gilchrist, 1994, Kashyap et. al., 1994, Kashyap, Stein, 2000, Campello, 2002 and Loutskina, 2011). Others use natural experiments, where external shocks from abroad propagate into domestic credit markets through cross-border ownership of banks (e.g., Peek and Rosengren, 1997, Schnabl, 2012, Cetorelli and Goldberg, 2012). Our study is closest to those evaluating how local liquidity shocks from bank failures, government interventions or bank runs affect lending supply (Ashcraft, 2006, Khwaja and Mian, 2008, Paravisini, 2008, Iyer and Peydro, 2011). We analyze how a positive exogenous liquidity shock propagates to other markets and document the on-balance-sheet and aggregate lending supply elasticities with respect to deposit growth. We isolate supply effects by exploiting data with precise information on the location of both lender (branch location) and borrower (property location).

In the remainder of the paper, Section II describes briefly the shale booms and their effects on local banks. Section III describes our data, and Section IV reports empirical methods and results. Section V contains a brief conclusion.

\section{SHALE BOOMS}

In 2003, a surprise technological breakthrough combined horizontal drilling with hydraulic fracturing (“fracking”) and enabled vast amounts of natural gas shale to become

\footnotetext{
${ }^{4}$ See the theoretical arguments in, e.g., Bernanke and Blinder (1988), Holmstrom and Tirole (1997), and Stein (1998).
} 
economically profitable to develop. Subsequent prospecting activity led to the development of a new energy resource equivalent to 42 years of U.S. motor gasoline consumption. As recently as the late 1990s, these reserves were not thought to be economically viable, and represented less than $1 \%$ of U.S. natural gas production.

The breakthroughs in the development of the Barnett Shale near Fort Worth, TX in 2003 changed industry notions on the viability of natural gas shale. The Barnett Shale was initially drilled by Mitchell Energy in the early 1980s (Yergin, 2011). Rather than encountering the highly porous rock of a conventional formation, however, Mitchell encountered natural gas shale. While shale holds vast amounts of natural gas, it is highly non-porous and traps the gas in the rock. After 20 years of experimentation, in the early 2000s Mitchell Energy found that hydraulic fracturing ("fracking”) could break apart shale and free natural gas for collection at the surface. This breakthrough combined with new technology for horizontal drilling and higher natural gas prices made large new reserves from shale economically profitable to develop.

The size of this energy resource and the low risk of unproductive wells (“dry-holes”) has led to a land grab for mineral leases. Before commencing any drilling operations, oil and gas firms must negotiate leases with mineral owners. Typically these contracts are comprised of a large upfront "bonus" payment, paid whether the well is productive or not, plus a royalty percentage based on the value of the gas produced over time. The resulting wealth windfalls led to large increases in local bank deposits. In an interview with the Houston Chronicle (2012), H.B. “Trip” Ruckman III, president of a bank in the Eagle Ford shale, stated "We have had depositors come in with more than a million dollars at a whack.” This statement is consistent with reports of leasing terms. For example, an individual who owns one square mile of land (640 acres) and leases out his minerals at $\$ 10,000 /$ acre would receive an upfront one-time 
payment of $\$ 6.4$ million plus a monthly payment equal to $25 \%$ of the value of all the gas produced on his lease.

The deposit windfalls experienced by banks with branches in boom counties were exogenous to the underlying characteristics of the affected communities for a number of reasons. First, the technological breakthroughs, horizontal drilling and hydraulic fracturing, were unexpected, and the viability of these technologies in different geographies was uncertain. Highlighting the fast paced and unexpected nature of these discoveries, the New Orleans' TimesPicayune (2008) reported an increase in lease bonus payments from a few hundred dollars an acre to $\$ 10,000$ to $\$ 30,000$ an acre in the Haynesville Shale area within a one year time period. Second, the economic viability of the wells was determined by larger macroeconomic forces, such as demand for natural gas and natural gas prices (Lake, Martin, Ramsey, and Titman(2012)), and therefore was unrelated to the local economic conditions (health, education, demographics, etc.). Third, because fracking was a relatively new technology, predicting how many wells in an area might be needed to develop recoverable resources was challenging. These characteristics together suggest that it was unlikely that banks could strategically alter branch structures to gain greater exposure to shale windfalls. Thus, bank deposit windfalls from shale discoveries are an attractive setting to study the role of branch networks in financial integration.

\section{Data ANd SAMple Selection}

Our sample is based on lending activity in the seven states with major shale discoveries during the 2003-2010 time period: Arkansas, Louisiana, North Dakota, Oklahoma, Pennsylvania, Texas and West Virginia. As Figure 1 shows, each state contains a large number of counties that experienced shale booms as well as a large number of non-boom counties. Across the seven states, 124 counties experienced booms and 515 did not. Our sample, built at the bank-county- 
year level, includes all banks making housing-related loans (home purchase mortgages, mortgages for re-financing, and home equity loans) in any of these seven states. We consider all lenders irrespective of their branch locations (i.e., including loans originated without brick and mortar presence in a county) or exposure to the booms. We drop all non-bank lenders because most fund mortgage lending with securitization and are thus not affected by local liquidity shocks. The sample begins in 2000 (three years before the first shale boom), and ends in 2010 . Using the Summary of Deposits from the Federal Insurance Deposit Corporation (FDIC), we determine the number of branches and amount of deposits held by each bank in each countyyear in the seven states. ${ }^{5}$ These data allow us to build two alternative measures of exposure to the shale-boom shocks. The first - Share of Branches in Boom Counties - equals the fraction of branches owned by each bank that are located in a shale-boom county. The measure ranges from zero (for banks without branches in boom counties, or for banks with branches in boom counties during the years prior to a boom's onset) to one (for banks with all of their branches in boom counties after the onset of the booms). This variable equals zero for all bank-years prior to 2003, the year of the first shale investment. After 2003, the variable increases within bank over time as more counties experience booms.

Our second measure accounts for both the distribution of branches across counties as well as the size of the shale investments (as a proxy for the amount of money being deposited into local branches). This measure - Growth in Shale Well Exposure - equals the weighted exposure to the growth in the number of shale wells, where the fraction of a bank's branches in each county serves as weights. This measure is harder to interpret than the Share of Branches in

\footnotetext{
${ }^{5}$ http://www2.fdic.gov/sod/.
} 
Boom Counties - it need not vary between zero and one - but it accounts for differences in the relative size of the booms.

Our models focus on the effect of exposure to the shale boom on mortgage credit growth, but we include other bank characteristics as control variables, each measured from the end of the prior year. These variables include the following: Log of Assets $_{\mathrm{t}-1}$; Deposits/Assets $\mathrm{t}_{\mathrm{t}-1}$; Cost of Deposits $_{\mathrm{t}-1}$ (=interest expenses on deposits / total deposits); Liquid Assets / Assets $\mathrm{t}_{\mathrm{t}-1}$; Capital / Assets $_{\mathrm{t}-1}$ (=Tier 1 capital/ assets); C\&I Loans / Asset t-1 $_{\text {; }}$ Mortgage Loans / Assets $\mathrm{t}_{\mathrm{t}-1}$; Net Income / Assets $_{\mathrm{t}-1}$; Loan Commitments / Assets $_{\mathrm{t}-1}$; and, Letters of Credits /Assets $\mathrm{t}_{\mathrm{t}-1}$. Data for bank control variables come from year-end Call Reports. We merge Call Report and HMDA as in Loutskina and Strahan (2009).

Table 1 reports summary statistics for our two measures of banks' exposure to the shale well boom - Share of Branches in Boom Counties and Growth in Shale Well Exposure (Panel A), as well as the lagged bank characteristics (Panel B), separated by whether or not the bank has any exposure to a shale-boom county. Table 1 shows that exposed banks tend to be larger than non-exposed banks and that their deposits grow faster, consistent with the notion that exposure to the shale boom leads to strong deposits inflows. The marked difference in asset size (log of assets) is a potential concern in our models because large banks differ in many ways from smaller ones, so we will report robustness tests in which we filter out larger banks.

To measure mortgage activity, we utilize the detailed data on mortgage applications collected annually under the Home Mortgage Disclosure Act (HMDA). Whether a lender is covered depends on its size, the extent of its activity in a Central Business Statistical Area 
(CBSA), and the weight of residential mortgage lending in its portfolio. ${ }^{6}$ The HMDA data include loan size, whether or not a loan was approved, as well as some information on borrower characteristics. Using HMDA data, we measure mortgage origination growth by bank-countyyear. HMDA reports both the identity of the lender as well as the location of the property down to the census-tract level. These are the only comprehensive data on lending by US banks that allow researchers to locate borrowers geographically. In principle we would also like to test for similar effects on other kinds of loans (especially loans to small businesses), but micro data at loan level are not available outside of housing. HMDA also contains information on the purpose of the loan (mortgage purchase loans, home-equity loans, and mortgage re-financings) and whether the lender expects to sell or securitize the loan within one year of origination. We use these data to test whether loans easier to finance in securitization markets respond less to the local deposit inflows that follow shale booms.

Panel C of Table 1 reports summary statistics for the mortgage growth rates. For the average exposed bank, mortgages grow $11.7 \%$ per year, compared to $11.2 \%$ for banks not exposed. This difference is larger for retained mortgage growth, which averages $9.1 \%$ per year for exposed banks, compared to $7.7 \%$ for non-exposed banks. These raw differences could be attributed to both the deposit windfalls as well as to economic growth of the boom counties. We isolate these two effects in our regressions. Note that the standard deviation in the mortgage growth rates is very high relative to the mean, but most of this variation reflects time-series fluctuations stemming from changes in interest rates (which alter re-financing rates drastically)

\footnotetext{
${ }^{6}$ Any depository institution with a home office or branch in a CBSA must report HMDA data if it has made a home purchase loan on a one-to-four unit dwelling or has refinanced a home purchase loan and if it has assets above \$30 million. Any non-depository institution with at least ten percent of its loan portfolio composed of home purchase loans must also report HMDA data if it has assets exceeding \$10 million. Consequently, HMDA data does not capture lending activity of small or rural originators. U.S. Census shows that about 83 percent of the population lived in metropolitan areas over our sample period and hence the bulk of residential mortgage lending activity is likely to be reported under the HMDA.
} 
as well as variation around the housing boom (2004-2006) and bust (2006-2010) periods, which our data straddle.

HMDA also contains some borrower characteristics, which we use to build the following control variables for all loans originated at the bank-county-year level: borrower and area income, loan size-to-borrower-income ratio, percent women and percent minority, and percent minority in the area for loans. In all of our models we control for the contemporaneous means of each of these borrower attributes across all loan originations in a given bank-county-year.

\section{Methods AND Results}

\section{Instrumental Variable Analysis}

To test how deposit shocks affect lending, we estimate the following relationship:

Mortgage Growth $h_{i, j, t}=\alpha_{j, t}+\beta \cdot$ Deposit Growth $h_{i, t}+$ Borrower \& Lender Controls $+\varepsilon_{i, j, t}$,

where $i$ indexes lenders, $j$ indexes counties, and $t$ indexes years. The county*year fixed effects $\left(\alpha_{j, t}\right)$ remove time-varying, county-level demand-side shocks related to business cycles, industry composition, housing demand, etc. To further separate supply shocks from potentially confounding demand shocks, we include in our sample only counties that did not experience a shale boom during the $2000-2010$ period.

We use two alternative measures of a bank's exposure to the shale booms as instrumental variables for deposit growth: Share of Branches in Boom Counties and Growth in Shale Well Exposure. Unlike the growth in lending volume, the measures of deposit growth, as well as the instruments, do not vary across counties for a given bank-year. Since, there could be common, time-invariant bank-level components to the error term, we build standard errors by clustering by bank throughout all of our results. 
We first model total mortgage originations growth as the dependent variable, and then we decompose Mortgage Growth ${ }_{i, j, t}$ into the growth in retained mortgages and the growth in sold or securitized mortgages. This decomposition offers a number of advantages. First, it allows us to document the true on-balance-sheet elasticity of total lending to a deposit supply shock. Second, it allows us to evaluate whether a deposit shock leads banks to retain more loans at the expense of the secondary market. The ability of the capital markets to absorb securitized loans should not be affected, but a bank’s willingness to supply such loans to the secondary market might change with their financial conditions. Finally, the decomposition allows us to further validate our identification strategy.

Table 2 reports the IV and OLS estimates of (1). Columns (1) and (2) contain first-stage results, one using Share of Branches in Boom Counties and the other using Growth in Shale Well Exposure. As expected, deposits grow faster at banks with a greater fraction of branches in shale-boom counties. The instrument has a t-statistic of 1.97 (column 1) or 3.10 (column 2); in both cases we pass the Kleibergen-Paap weak identification test and the Anderson-Rubin Chisquare and F-tests for significance of endogenous regressors. Since the model is just identified, we cannot report over-identification tests. Columns (3), (5) and (7) report the OLS versions, and columns (4), (6) and (8) report the IV estimates for comparison. The reported IV analysis corresponds to the first-stage equation in column (1). The IV results based on Growth in Shale Well Exposure instrument are qualitatively and quantitatively similar.

Notably, the OLS coefficients are positive and significant with very similar magnitudes across all three mortgage-growth variables, ranging from about 0.4 to 0.6 . However, when we isolate the deposit supply-shock channel, we observe significantly different elasticities across the three loan categories. The supply shock leads to an increase in overall lending activity, with a 
one percent increase in bank deposits leading to a 0.93 percent growth in loan origination. This effect comes mostly from banks originating and retaining more loans but not at the expense of securitizing less. The coefficient suggests that a one percent increase in deposit growth (from an external liquidity supply shock) causes a 2.3 percent increase in the growth of retained mortgages. An elasticity above one implies that other portions of the bank's balance sheet, such as investments in securities or other liquid assets, are not affected or even decline when deposit supply expands. Investments in liquid assets, for example, may decline in response to the shaleboom windfalls, although we have no clean way to identify this relationship because such investments have no geographical component. Overall, these results suggest that a deposit inflow expands lending rather than merely redistributing loans away from the securitization market and onto banks’ balance sheets.

Unobserved bank characteristics are unlikely to be able to explain our key results. The bank-year level control variables in Table 2 have relatively little explanatory power in these regressions. Moreover, the results of interest are similar when these variables are excluded (not reported).

\section{Do Banks Enter 'Boom' Counties to Chase Funds?}

One concern may be that, after observing the advent of shale-boom discoveries in 2003, banks strategically enter shale-boom counties (or counties with known shale reserves) to raise low-cost deposits. If such entry were motivated by the need to fund loans, then our effects could be driven by both supply and demand factors, thus invalidating our identification strategy. ${ }^{7}$

\footnotetext{
${ }^{7}$ For example, Ben-David, Palvia and Spatt (2013) report evidence of banks increasing demand for deposits (and hence prices) locally when they face higher loan demand in out-of-state markets connected through branches.
} 
We address this concern by directly testing whether banks with higher loan demand subsequently increase their exposure by entering shale-boom counties. Specifically, we evaluate what share of a bank's boom exposure measures is attributed to its 2002 branch distribution and whether bank-specific loan demand affects the remaining variation in exposure. The distribution of branches in 2002 could not have been motivated by demand for funds by banks because shale booms started unexpectedly in 2003. We build the 2002-branch-network exposure proxies using only the time variation in county shale booms (Share of 2002 Branches in Boom Counties $_{i, t}$ and Growth in Exposure from 2002 Branches $_{i, t}$ ). These measures capture exposure to the boom that would have occurred if each bank had held constant its 2002 branch network. We then run the following regression specifications:

Share of branches in boom counties $i_{i, t}=\gamma_{1}$ •Share of 2002 Branches in Boom Counties $i_{i, t}+$ $\gamma_{2} \bullet$ Mortgage Growth $h_{i, t-1}+\gamma_{3} \bullet$ Mortgage Growth ${ }_{i, t-2}+$ Control Variables $+\varepsilon_{i, t}$,

and

Growth in Shale Well Exposure $_{i, t}=\gamma_{1}{ }^{\bullet}$ Growth in Exposure from 2002 Branches $_{i, t}+$ $\gamma_{2} \bullet$ Mortgage Growth ${ }_{i, t-1}+\gamma_{3} \bullet$ Mortgage Growth ${ }_{i, t-2}+$ Control Variables $+\varepsilon_{i, t}$,

where the unit of observation is bank $i$ - year $t$.

If banks' exposure to the boom is solely due to the time variation in onsets of boom throughout the counties, then we expect $\gamma_{1}=1$. If banks facing higher loan demand (captured by past loan or application growth) enter booming markets to access cheap deposits, then we expect $\gamma_{2}>0$ and/or $\gamma_{3}>0$. We estimate (2a) and (2b) over the 2003 to 2010 period because these are the years when the shale booms occur. The sample contains all banks that originated mortgages in at least one county in the seven states that experience shale booms. 
Table 3 reports the estimates of (2a) in Panel A and (2b) in Panel B with different sets of control variables. The 2002 branch distribution explains the vast majority of subsequent exposure to the shale booms. In the simple models, $\mathrm{R}^{2}$ exceeds $92 \%$. Moreover, t-statistics on Share of 2002 Branches in Boom Counties (Growth in Exposure from 2002 Branches) never fall below 50. At the same time, past loan growth has almost no explanatory power. Even in column (2) of Panel B, where the coefficient $\gamma_{3}$ is statistically significant at the $10 \%$ level, the effect of past loan growth on boom exposure is economically negligible. Since loan growth may be an imperfect proxy for loan demand, in an unreported set of tests we find that the past growth in loan applications also does not explain the residual variation in banks' shall boom exposure measures. Overall, there is no evidence that banks with high loan demand systematically enter (or purchase branches in) shale-boom counties.

\section{Reduced Form Approach}

We have established that lending growth responds positively to deposit windfalls from external markets. In the remainder of the paper we evaluate which markets and loan types benefit most from the windfalls from shale-boom exposure. To explore these questions we simplify the empirical set-up and focus on reduced forms linking a bank's shale-boom exposure to its lending in non-shale counties. The reduced form approach allows us to test for interaction effects, which would be difficult to estimate in the IV setting. As a first step, however, we present the reduced form models that correspond to the instrumental variable analysis presented in Table 2 and evaluate the robustness of our core results. The baseline reduced form model is as follows: 


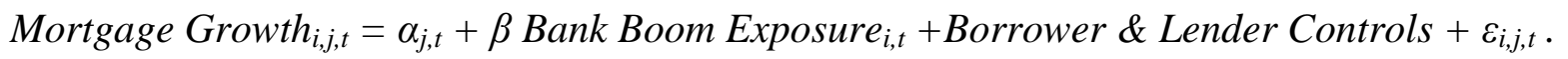

Table 4 reports the results. Consistent with the instrumental variable analysis (Table 2), we find significant positive effects of exposure to shale-booms on both total mortgage growth (columns $1 \&$ 2) and growth of retained mortgages (columns $3 \& 4$ ), but no significant effect on sold-loan growth (columns $5 \& 6$ ). For retained mortgages, a typical exposed bank (e.g. one with about $45 \%$ of its branches in a shale-boom county - recall Table 1) would grow its retainedmortgage portfolio 14 percentage points $\left(=0.45^{*} 0.325\right)$ faster in the non-boom counties than a similar bank without exposure to the shale-boom windfalls (based on the coefficient of interest in column 3). Similar to Table 2, the bank-year level control variables have relatively little explanatory power and the coefficients of interest are similar when these variables are excluded.

Furthermore, our reduced form model results withstand a wide set of robustness tests presented in Table 5. First, we evaluate whether our results could be attributed to the shaleboom exposed banks systematically lending more irrespective of the boom. That is, we test whether the parallel trends assumption between 'treatment' and 'control' banks is violated. Columns (1) and (2) of Table 5 test whether banks exposed and not exposed to booms behave similarly before the booms actually occur. We create the variable Pre-boom Indicator for Booming Banks, equal to one for booming banks during all years prior to an actual boom. For example, the indicator would be set equal to one during 2000-2006 for a bank that first became exposed to a shale-boom county in 2007. The indicator would be equal to zero for all years after 2006 in this example. For banks that never experience exposure, the indicator equals zero for all years. By introducing this variable, we can rule out the possibility that banks which experience booms (the treatment group) behave differently from other banks (control group) during 'normal' times. Consistent with this notion, the coefficient on this variable is never significant. 
Second, we rule out the possibility that our results are driven by banks whose branches happen to be closer to shale-boom counties grow faster than other banks in the same county. If some banks' lending grows faster due to demand spill-overs from neighboring boom counties, then our results could be driven by both supply- and demand-side shocks. We evaluate the validity of this hypothesis by simply dropping all counties that abut boom counties (columns 3 and 4). The results are similar to those reported in our baseline models and further support the notion that the elasticities we document are supply-side driven.

Third, the summary statistics presented in Table 1 indicate that the exposed banks tend to be larger than those never exposed to shale booms. The disparity occurs because large banks, by the very fact that they are large, will have a greater likelihood of having at least some exposure to counties with shale-booms. Large banks, however, also have wide access to the capital markets and, during the time of crisis, government financial support, and hence might grow their lending quicker than the rest of the banking sector. To evaluate this premise, we estimate equation (3) without banks with a very small (but non-zero) exposure to the boom counties (less than 2.5\%). This filter removes the large, nationwide banks that are unlikely to be affected in a significant way by local variation in deposits. Moreover, when we impose this filter the average asset size for exposed vs. unexposed banks becomes very close ( $\$ 400$ vs. $\$ 465$ million), as opposed to the unfiltered data (recall Table 1). The coefficients on both Share of Branches in Boom Counties and Growth in Shale Well Exposure increase in magnitude and statistical significance when we impose this filter (0.17 v. 0.15 in column (5); 0.06 v. 0.05 in column (6)).

Fourth, we estimate equation (3) after dropping bank-county-years where the mortgage growth rate is based on fewer than 15 loans during the prior year (columns (7) and (8)). This filter drops observations likely to have substantial noise in the dependent variable. Again, the 
results are stronger than before, both in terms of magnitudes as well as statistical significance. This indicates that our results cannot be attributed to noise in measuring the changes in banks' origination decisions.

In the fifth and final robustness test, we add bank*county fixed effects (columns (9) and (10)). Adding these removes the possibility that some banks may always grow faster than others within the same county. For example, some banks may simply have more advertising in specific areas or branches in better locations, leading to persistently higher rates of mortgage growth. In fact, adding the bank*county effects increases the magnitude and statistical significance of our results.

Note that in Table 5 and hereafter, we focus on total mortgage origination, although as we have documented the effects are driven by variation in retained (as opposed to sold) mortgage growth. The core focus of this paper is to evaluate whether bank deposit inflows affect overall lending supply as opposed to exploring the shocks' effects on a bank's decision to finance lending on balance sheet or through loans sales/securitization. Loutskina and Strahan (2009) have established that the decision to hold or sell a mortgage at the margin depends on a bank's funding cost, which varies with exposure to the shale booms in the setting of this paper.

\section{Where Do Local Shocks Matter?}

Theory suggests that an increase in deposits should only affect credit supply for loans where contracting frictions make arm's length finance difficult, either because lenders have better information than investors or because incentives for lenders to engage in sufficient monitoring would diminish if a loan were sold (e.g., Gorton and Pennacchi, 1995, Holmstrom and Tirole, 1997, Keys et al, 2010). If a lender has no information or monitoring advantage relative to any other lenders - if the lending decision depends only on public information such as 
borrower FICO scores and mortgage loan-to-value ratios - then we would expect changes in bank funding to have no impact on their credit supply decisions. These markets would be highly commoditized and competitive.

In contrast, changes in local funding could affect credit supply in market segments where frictions require soft information production and thus erect barriers to non-local lenders or to local lender securitizing their originations. In line with these arguments, we should see deposit inflows being exported to markets with more contracting frictions and those where lenders have informational advantage over the other financial intermediaries.

Based on these ideas, we first evaluate whether deposit windfalls increase lending more in counties where banks have branches, as compared to counties where they lend without a brick and mortar presence. Extant literature suggests that local lenders have an informational advantage as they tend to lend to more opaque and riskier firms. Mortgage lenders with branches near their borrowers also have an advantage in monitoring borrowers that may experience distress. Figure 2 further validates the underlying assumption that a local branch presence allows banks to produce more soft information about borrowers by presenting securitization rates for mortgage loans made in the seven states that we study. Specifically, it compares loans originated by banks with (local) and without (non-local) a branch in the same county as the property being financed. These figures show that mortgages made by local lenders are consistently securitized or sold at much lower rates than those made by non-local lenders; the difference is nearly 30 percentage points, on average. ${ }^{8}$

\footnotetext{
${ }^{8}$ A natural way to sort our data would be based on whether or not Fannie or Freddie will provide credit guarantees, such as comparing jumbo and non-jumbo mortgages. Unfortunately, the markets we study have low real estate prices so that the vast majority of loans fall into the non-jumbo category.
} 
Second, we evaluate the effect of deposit windfalls by mortgage type. Contracting frictions should be most pronounced for home-equity loans (because these are often subordinated), and least for mortgage re-financing (because borrowers have an established payment history), with home purchase originations being between these two extremes. Consistent with this notion, securitization rates are lowest among home-equity loans (4.5\%), highest among mortgage refinancing loans (65\%), with mortgages for home purchase in the middle (46\%).

So, we expect local lenders (those with branches in the same county as the borrower) to respond more to the deposit windfalls than non-local lenders. Similarly, we expect home-equity loan growth to respond most to the deposit shock, and re-financings least. To test these ideas, we first introduce an interaction to the reduced form models based on whether or not the bank has a branch located near the borrower:

$$
\begin{aligned}
& \text { Mortgage Growth }_{i, j, t}=\alpha_{j, t}+\beta_{1} \text { Local Lender }_{i, j, t}+\beta_{2} \text { Bank Boom Exposure } i_{i, t}+ \\
& \quad+\beta_{3} \text { Local Lender }_{i, j, t} * \text { Bank Boom Exposure }{ }_{i, t}+\text { Borrower, Lender Controls }+\varepsilon_{i, j, t}
\end{aligned}
$$

In equation (4), Local Lender $r_{i, j, \mathrm{t}}$ equals one if a lender $i$ has at least one branch in county $j$ in year $t$ and zero otherwise. The coefficient $\beta_{3}$ can be interpreted as the relative difference in the effect of having a local branch versus providing the financing at arm's length. Columns (1) and (2) if Table 6 report results using all lenders, and includes the interaction term to identify $\beta_{3}$. Columns (3) and (4) of Table 6 report the model without the interaction term, including just the local-lender sample of bank-county-years.

We find mortgage growth increases for banks exposed to shale-boom windfalls, but only for local banks - those with branches in the same county as the property being financed. The interaction term is positive and significant (columns 1 and 2), and the overall impact on local 
banks is itself significant (columns 3 and 4). The direct effect of the deposit windfall, however, is not significant (columns 1 and 2), meaning that lending in counties where exposed banks do not have branches does not change. Comparing the typical local bank with exposure (Share of Branches in Boom Counties = 0.45, recall Table 1) to a local bank without exposure (Share of Branches in Boom Counties = 0), mortgage lending would grow 10 percentage points faster $(=0.45 * 0.23$, based on column 3$)$ at the exposed bank. There is no evidence that lenders exposed to the shale-boom windfalls would supply more credit to geographies where they do not have branches (i.e. neither the direct effect of Share of Branches in Boom Counties nor Growth in Shale Well Exposure is significantly different from zero). Table 6 thus establishes that local windfalls stimulate lending only in markets connected through bank branching networks.

Next, we incorporate loan type by estimating Equation (4) separately for home equity loans, mortgages for home purchase, and mortgages for refinancing. ${ }^{9}$ Table 7 reports only the coefficients of interest, but the specification includes the same set of borrower and lender controls and county*year fixed effects as the previous sets of results. Consistent with the earlier analysis, only local lenders respond to the deposit windfalls. Moreover, their response is evident only among loans that are hard to securitize (and subject to more contracting frictions): mortgages for home purchase and home equity loans, but not mortgages for re-financing. In these specifications, the effects of the deposit windfall are largest for the home-equity segment, intermediate for mortgages for home purchase, and zero for the re-financing segment.

\footnotetext{
${ }^{9}$ Samples differ across the three columns in Table 7 because we model the growth rate in lending, so a bank-county only appears if there are non-zero originations in two consecutive years.
} 


\section{Is New Mortgage Lending a Free-Cash-Flow Agency Problem?}

Our results suggest that portions of the mortgage market where local knowledge limits the impact of securitization and arm's length finance respond to local liquidity shocks from deposit inflows. This increase, however, could reflect lender agency problems (Jensen, 1986) whereby unexpected cash inflows lead managers to over-invest and destroy value (i.e. marginal loans have $\mathrm{NPV}<0$ ). The agency explanation is hard to rule out fully because we are not able to follow loan outcomes at the bank-county-year level. ${ }^{10}$

Instead, we consider lending in the boom counties themselves. If the windfalls are large, then all banks ought to be able to fully exploit profitable lending opportunities within the boom counties; thus, mortgage lending growth in the boom counties should not vary as a bank's access to external (non-boom) counties changes. On the other hand, if agency problems are motivating the increase in lending, then banks confined to boom counties without access to external lending markets (that is, banks with branches only in booming counties) would expand lending more than other exposed banks.

To test this idea, we add the boom counties to our panel and include interaction terms to allow the effects of Bank Boom Exposure proxies to vary depending on whether a county itself is experiencing a shale boom. Thus, we estimate the following regression:

$$
\begin{aligned}
\text { Mortgage Growt }_{i, j, t}= & \alpha_{j, t}+\beta_{1} \text { Bank Boom Exposure } \\
i, t & + \\
& +\beta_{2} \text { Boom County }_{j, t} * \text { Bank Boom Exposure } \text { Ex }_{i, t}+\text { Borrower, Lender Controls }^{+} \varepsilon_{i, j, t}
\end{aligned}
$$

\footnotetext{
${ }^{10}$ Loan-level data on delinquencies and foreclosures is available, but assessing which investor actually bears losses is not. For example, when loans that have been securitized (or loans where originators have purchased credit protection from one of the GSEs) go bad, losses may not affect the originating lender, or such losses may be shared with other investors.
} 
where Boom County ${ }_{j, t}$ is an indicator variable equal to one if county $j$ in year $t$ is experiencing a shale well boom and zero otherwise. The direct effect of the indicator variable Boom-County ${ }_{i, t}$ is absorbed by the county-year effects. Thus, the results cannot be explained by the demand side shock associated with the onset of the shale boom in a county. For these tests, we include only local banks, since we have documented that only they adjust their lending in response to the shale-boom shocks.

As documented in Table 8, we find no significant relationship between the extent of connections to external markets and mortgage growth within the boom counties - all banks in these counties behave similarly with respect to local loan growth; for example: in column (1) the sum of the coefficient on Share of Branches in Boom Counties and the coefficient on its interaction with the Boom-County is approximately zero. Since all banks in boom counties are flush with deposits, they can fully exhaust their profitable loans there. In contrast, in the nonboom markets banks' increase in exposure to the deposit shock leads to increased lending. The effects estimated here are economically similar to those reported earlier for regressions that included just the non-boom counties. (These results are reproduced in Table 8 , columns 3 \& 4 for comparison.)

In addition, we provide two more tests to further confirm that the deposit inflows are allocated rationally by lenders. First, we test whether deposit inflows affect mortgage growth most in those markets with the highest un-served credit demand. If credit supply expands rationally to finance good projects (as opposed to managers' pet projects), we would expect a greater response in counties with more ex ante demand for credit. To measure un-served credit demand, we follow Mian and Sufi (2009), who argue that the advent of subprime credit had its greatest impact on neighborhoods with unmet demand for mortgage credit, based on the mean 
mortgage approval rate in the area at the beginning of their sample. Their analysis suggests that such areas experienced stronger growth in credit and housing prices, and then larger crashes after 2006. We apply their strategy to our setting by inter-acting our measure of external deposit windfalls with the average mortgage approval rate (based on HMDA data) from all mortgage applications made during the prior bank-county-year.

Second, we test whether financial constraints alter how banks react to the deposit windfalls. We introduce an interaction between our measures of exposure with the lag of the bank capital-asset ratio (known in regulatory parlance as the 'leverage ratio'). ${ }^{11}$ If credit expands rationally, banks with higher capital - banks less constrained by capital - can deploy their lowcost deposits to make more new loans; in contrast, more constrained banks would more quickly face binding regulatory capital constraints.

Table 9 reports these results, with each interaction term reported separately and then both together. (The direct effects of both the lagged approval rate and the lagged capital ratio are in the models but not reported.) Deposit windfalls spur lending most in areas with low mortgage approval rates, which we interpret as a proxy for un-satisfied demand for mortgage credit. ${ }^{12}$ We find large differences in the movement of funds depending on our measure of unmet demand. For example, when demand is low (lagged approval rate $=90 \%$ ), the coefficients in column 1 imply that exposed lenders (Share of Branches in Boom Counties $=0.45$ ) increase their mortgage loans by 7.5 percentage points more than unexposed lenders. In contrast, when un-served credit

\footnotetext{
${ }^{11}$ We find similar results if we used the bank's ratio of Tier 1 capital to risk weighted assets.

${ }^{12}$ In fact, the lagged approval rate is strongly correlated with mortgage growth - markets with high approval rates grow more slowly, validating the interpretation of this variable as a measure of unmet credit demand - but adding this variable does not change the overall effect of the liquidity windfall variables.
} 
demand in high (lagged approval $=50 \%$ ), the exposed banks increase mortgages 22 percentage points faster than unexposed ones.

Financial constraints also affect the impact of the deposit shocks. Capital potentially limits the extent to which a bank may deploy a given inflow from branches located in shaleboom counties because banks must operate above regulatory required minimum capital ratios. Since capital is costly to increase in the short run, especially for small and medium sized banks without access to public markets, we would expect the impact of the shock to increase with the ratio of capital to assets. ${ }^{13}$ Consistent with this notion, the interaction of Share of Branches in Boom Counties (Growth in Shale Well Exposure) with capital is positive and significant, both economically and statistically.

To understand magnitudes, consider first the difference in lending between exposed (Share of Branches in Boom Counties = 0.45) and non-exposed banks with high approval rates (=0.9, implying little un-served credit demand) and low capital ( $=0.07$, one sigma below the mean). Our coefficients suggest that the exposed bank would grow its lending by just 2 percentage points faster than the non-exposed bank (using coefficients from column 3). Taking the other extreme, next consider the difference in lending between exposed and non-exposed banks with low approval rates (=0.5, implying substantial un-served credit demand) and high capital ( $=0.13$, one sigma below the mean). In this case the coefficients suggest that the exposed bank would grow its lending 26 percentage points faster than the non-exposed bank. Thus, banks with high demand for credit that are able to deploy the deposit windfalls (due to high levels of ex ante capital) grow their mortgage portfolios very substantially.

\footnotetext{
${ }^{13}$ We have also tested other possible measures of a bank's financial constraints, such as asset size or holdings of liquid assets; these are not significantly related to the size of the liquidity shock's impact on mortgage growth.
} 


\section{Conclusions}

We have provided evidence of the importance of bank branch networks in fully integrating segments of local credit markets that are subject to financial contracting frictions. Shale-boom discoveries provide large and unexpected liquidity windfalls at banks with branches nearby as mineral-rights owners deposit large amounts of their new wealth into local banks. Mortgage lending increases as these banks export the liquidity windfalls into outlying (nonboom) markets, but only when such banks have branches in both markets. Banks experiencing deposit inflows do not export liquidity and lend more in areas where they have no branch presence because, we argue, without a branch presence banks cannot collect soft information about the borrowers and thus have no advantage over securitization markets.

Our results provide ‘smoking gun’ evidence that bank branching fosters financial integration by allowing savings collected in one locality (shale-boom counties) to finance investments in another (non-boom counties). The result is important for two reasons. First, it demonstrates the limits to arm’s length financing technologies like securitization in integrating

financial markets. For credit markets that require lenders to locate near borrowers to adequately understand and monitor risk, securitization is not a viable financing mechanism. Second, by allowing capital to flow more easily across local markets, deregulation of bank branching fostered a denser branch network that improved capital mobility and thus investment allocation efficiency. Better quality investment can help explain why broad economic outcomes like growth and volatility improved after branching reform. 


\section{References}

Agrawal, S., Hauswald, R., 2010, “Distance and Private Information in Lending,” Review of Financial Studies 23, 2757-2788.

Ashcraft, A., 2006, “New Evidence on the Lending Channel,” Journal of Money, Credit, and Banking 38, 751-776.

Beck, T., Levine, R., Levkov, A., 2010 “Big Bad Banks? The Winners and Losers from Bank Deregulation in the United States,” Journal of Finance 65, 1637-1667.

Berger, A. N., Miller, N. H., Petersen, M. A., Rajan, R. G., Stein, J. C., 2005, “Does Function Follow Organizational For? Evidence from the Lending Practices of Large and Small Banks,” Journal of Financial Economics 76, 237-269.

Bernanke, B. S., Blinder, A. S., 1988, “Credit, Money, and Aggregate Demand,” American Economic Review 78, 435-439.

Black, S. E., Strahan, P. E., 2001, "The Division of Spoils: Rent-Sharing and Discrimination in a Regulated Industry,” American Economic Review 91, 814-831.

Black, S. E., Strahan, P. E., 2002, “Entrepreneurship and Bank Credit Availability,” Journal of Finance 57, 2807-2833.

Campello, M., 2002, "Internal Capital Markets in Financial Conglomerates: Evidence from Small Bank Responses to Monetary Policy,” Journal of Finance 57, 2773-2805.

Cetorelli, N., Goldberg, L., 2012, “Bank Globalization and Monetary Policy,” Journal of Finance.

Cetorelli, N., Strahan, P. E., 2006, "Finance as a Barrier to Entry: Bank Competition and Industry Structure in Local U.S. Markets,” Journal of Finance 61, 437-461.

Cortes, K. R., 2011 "Did Local Lenders Forecast the Bust? Evidence from the Real Estate Market,” Working Paper.

Degryse, H., Ongena, S., 2005, “Distance, Lending Relationships, and Competition,” Journal of Finance 60, 231-266.

Gertler, M., Gilchrist, S., 1994, "Monetary Policy, Business Cycles, and the Behavior of Small Manufacturing Firms,” Quarterly Journal of Economics 109, 309-340.

Gilje, E. P., 2011, "Does Local Access to Finance Matter? Evidence from U.S. Oil and Natural Gas Shale Booms,” Working Paper. 
Gorton, G. B., Pennacchi, G. G., 1995, "Banks and Loan Sales: Marketing Nonmarketable Assets,” Journal of Monetary Economics 35, 389-411.

Holmstrom, B., Tirole, J, 1997, "Financial Intermediation, Loanable Funds, and the Real Sector,” Quarterly Journal of Economics 112, 663-691.

Houston Chronicle, 2012, “Eagle Ford Banks Challenged as Deposits Skyrocket,” June 8.

Iyer, R., Peydro, J., 2011, “Interbank Contagion at Work: Evidence from a Natural Experiment,” Review of Financial Studies 24, 1337-1377.

Jayaratne, J., Strahan, P., 1996, “The Finance-Growth Nexus: Evidence from Bank Branch Deregulation,” Quarterly Journal of Economics 111, 639-670.

Jensen, M., 1986, “Agency Cost of Free Cash Flow, Corporate Finance, and Takeovers," American Economic Review 76, 323-32.

Kashyap, A. K., Lamont, O. A., Stein, J. C., 1994, “Credit Conditions and the Cyclical Behavior of Inventories,” Quarterly Journal of Economics 109, 565-592.

Kashyap, A., Stein, J. C., 2000, "What do a Million Observations on Banks Say About the Transmission of Monetary Policy,” American Economic Review 90, 407-428.

Kerr, W. R., Nanda, R., 2009, "Democratizing entry: Banking Deregulations, Financing Constraints and Entrepreneurship,” Journal of Financial Economics 94, 124-149.

Keys, B., Mukherjee, T., Seru, A., Vig, V., 2010, "Did Securitization Lead to Lax Screening: Evidence from Subprime Loans,” Quarterly Journal of Economics 125, 307-362.

Khwaja, A. I., Mian, A., 2008, "Tracing the Impact of Bank Liquidity Shocks: Evidence from an Emerging Market,” American Economic Review 98, 1413-1442.

Lake, L. W., Martin, J., Ramsey, J. D., Titman, S., 2012, “A Primer on the Economics of Shale Gas Production,” Working Paper.

Levkov, A., 2012, “Branching of Banks and Union Decline,” Working Paper.

Loutskina, E., 2011, “The Role of Securitization in Bank Liquidity and Funding Management,” Journal of Financial Economics 100, 663-684.

Loutskina, E, Strahan, P.E., 2009, "Securitization and the Declining Impact of Bank Finance on Loan Supply: Evidence from Mortgage Acceptance Rates,” Journal of Finance 64, 861889. 
Loutskina, E., Strahan, P. E., 2011, "Informed and Uninformed Investment in Housing: The Downside of Diversification,” Review of Financial Studies 24, 1447-1480.

Mian, A., Sufi, A., 2009, "The Consequences of Mortgage Credit Expansion: Evidence from the U.S. Mortgage Default Crises,” Quarterly Journal of Economics 124, 1449-1496.

Morgan, D. P., Rime, B., Strahan, P. E., 2004, "Bank Integration and State Business Cycles," Quarterly Journal of Economics 119, 1555-1585.

Paravisini, D., 2008, “Local Bank Financial Constraints and Firm Access to External Finance,” Journal of Finance 63, 2161-2193.

Peek, J., Rosengren, E, 1997, “The International Transmission of Financial Shocks: The Case of Japan,” American Economic Review 87, 495-505.

Petersen, M. A., and Rajan, R. G., 2002, "Does Distance Still Matter? The Information Revolution in Small Business Lending,” Journal of Finance 57, 2533-2570.

Plosser, M., 2011, "Bank Heterogeneity and Capital Allocation: Evidence from 'Fracking' Shocks,” Working Paper.

Rice, T., Strahan, P. E., 2010, “Does Credit Competition Affect Small-Firm Finance,” Journal of Finance 65, 861-889.

Schnabl, P., 2012, "The International Transmission of Bank Liquidity Shocks: Evidence from an Emerging Market,” Journal of Finance 67, 897-932.

Stein, J. C., 1998, “An Adverse Selection Model of Bank Asset and Liability Management with Implications for the Transmission of Monetary Policy,” RAND Journal of Economics 29, 466-486.

Stiroh, K. J., Strahan, P. E., 2003, “Competitive Dynamics and Competition: Evidence from U.S. Banking,” Journal of Money, Credit, and Banking 35, 801-828.

Times-Picayune, 2008, "SWEET SPOT; A Recent Rush on Natural Gas Drilling in Northwest Louisiana is Turning Many Landowners into Instant Millionaires, and Stoking Others' Hopes," September 17.

Yergin, D., 2011 “The Quest: Energy, Security, and the Remaking of the Modern World,” The Penguin Press. 
Figure 1: Location of Shale Activity

The figure maps the counties of the 7 shale boom states included in this study: AR, LA, ND, OK, PA, TX and WV. White counties are non-boom counties while shaded counties are shale boom counties as of 2010 .

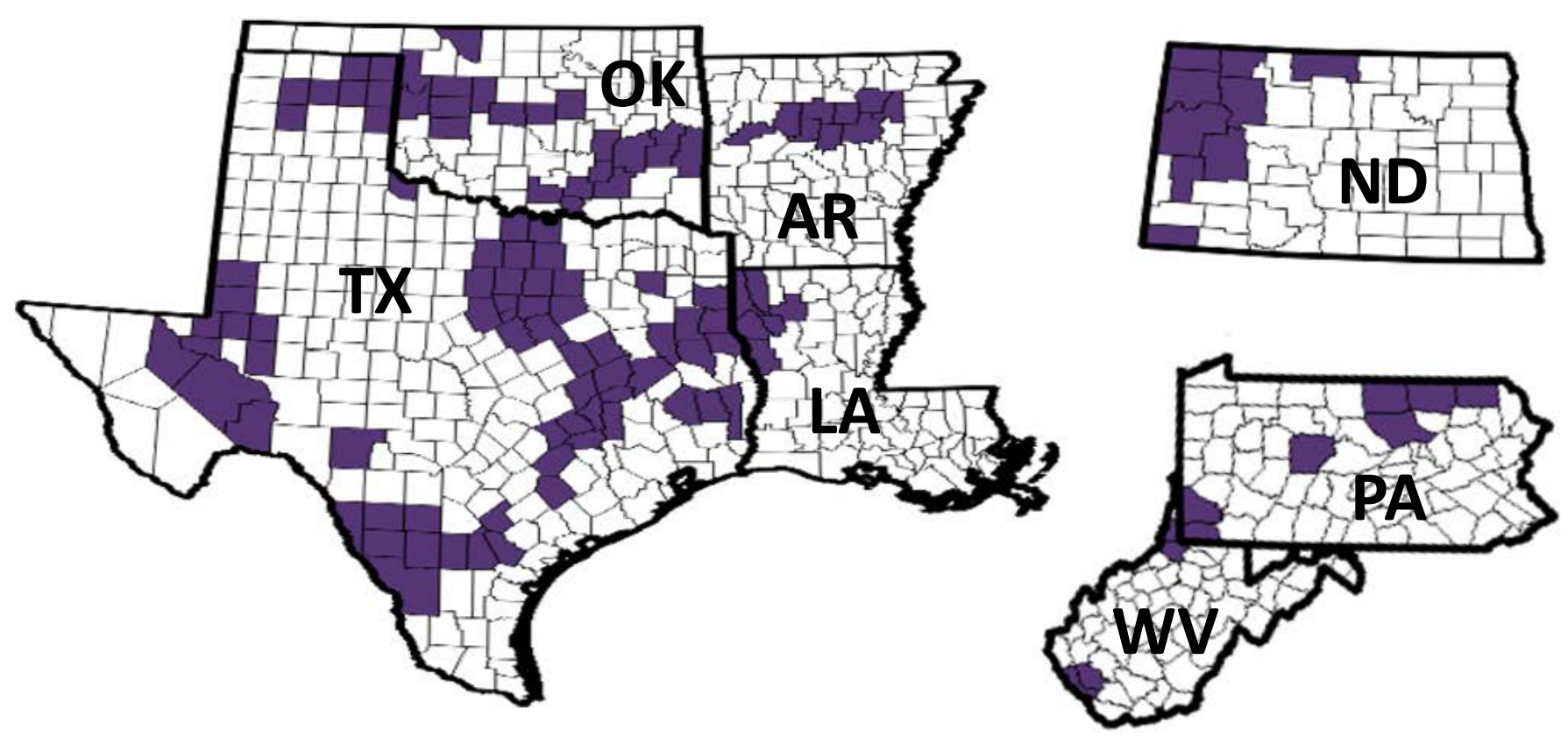


Figure 2: Securitization and Sold Rates, Local vs. Distant Loans

This figure plots the fraction of loans that are securitized or sold for local versus distant loans over the sample period in our study. A local loan is defined as a loan made in the same county in which a bank has a branch, while a distant loan is a loan made in a county by a lender that does not have a branch.

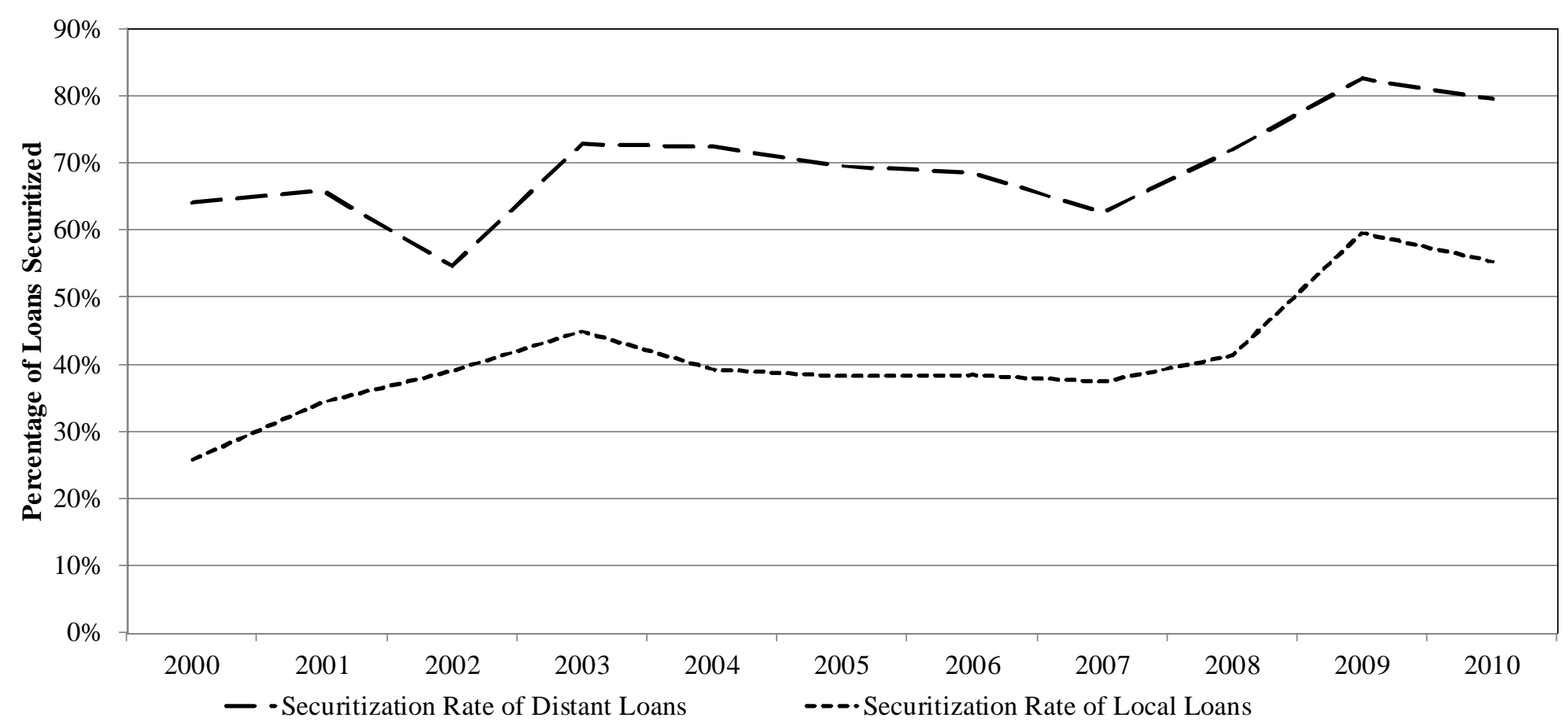




\section{Table 1: Summary Statistics}

This table reports summary statistics for banks operating in states with counties exposed to the shale boom. The unit of observation is bank-year in Panel A and Panel B, and bank-county-year in Panel C. The sample is built from the 7 states that experienced shale booms between 2000 and 2010. Share of Branches in Boom Counties equals the fraction of a bank's branches located in shale-boom counties (variable set to 0 before the onset of a shale boom). Growth in Shale Well Exposure equals the weighted exposure to the growth in the number of shale wells where the fraction of a bank's branches in boom counties serve as weights. The distribution of bank branches comes from the FDIC Summary of Deposits, which we use to determine whether or not a branch (or the bank that owns it) is or is not exposed to the boom. Bank characteristics come from year-end Call Reports. Growth in mortgage originations comes from the annual HMDA data.

\begin{tabular}{|c|c|c|c|c|}
\hline \multirow[b]{3}{*}{ Panel A: Exposure to Deposit Shock } & \multicolumn{2}{|c|}{$\underline{\text { Non-Exposed Banks }}$} & \multicolumn{2}{|c|}{$\underline{\text { Exposed Banks }}$} \\
\hline & Mean & Std. Deviation & Mean & Std. Deviation \\
\hline & & & & \\
\hline Share of Branches in Boom Counties & 0 & 0 & 0.45 & 0.39 \\
\hline Growth in Shale Well Exposure & 0 & 0 & 0.25 & 0.51 \\
\hline Number of Bank-Years & \multicolumn{2}{|c|}{7,451} & \multicolumn{2}{|c|}{1,280} \\
\hline \multicolumn{5}{|l|}{ Panel B: Bank Characteristics } \\
\hline$\overline{\text { Deposit Growth }}$ & 0.085 & 0.141 & 0.102 & 0.156 \\
\hline Log of Assets & 12.451 & 1.390 & 13.428 & 2.090 \\
\hline Deposits / Assets & 0.827 & 0.086 & 0.827 & 0.087 \\
\hline Cost of Deposits & 0.022 & 0.010 & 0.017 & 0.008 \\
\hline Liquid Assets / Assets & 0.273 & 0.148 & 0.225 & 0.132 \\
\hline Capital / Assets & 0.099 & 0.028 & 0.101 & 0.029 \\
\hline C\&I Loans / Asset & 0.112 & 0.090 & 0.145 & 0.087 \\
\hline Mortgage Loans / Assets & 0.347 & 0.137 & 0.323 & 0.117 \\
\hline Net Income / Assets & 0.009 & 0.008 & 0.008 & 0.011 \\
\hline Loan Commitments / Assets & 0.109 & 0.140 & 0.134 & 0.182 \\
\hline Letters of Credits / Assets & 0.006 & 0.011 & 0.010 & 0.020 \\
\hline \multicolumn{5}{|c|}{ Panel C: Annual Mortgage Growth Rates } \\
\hline Growth in Mortgage Originations & 0.112 & 0.621 & 0.117 & 0.576 \\
\hline Growth in Retained Mortgages & 0.077 & 0.672 & 0.091 & 0.618 \\
\hline
\end{tabular}




\section{Table 2: Effect of Deposit Supply Shock on Mortgage Lending}

This table compares OLS and IV regressions of the percentage change in mortgage originations by bank-county-year. The sample is built from bank-county-years in the 7 states that experienced shale booms between 2000 and 2010. Bank-county-years are excluded if the county actually experienced a shale-boom. Share of Branches in Boom Counties equals the fraction of a bank's branches located in shale-boom counties (variable set to 0 before the onset of a shale boom). Mortgage Growth equals the percentage change in originations from the prior year; Retained Growth equals the percentage change in mortgages held on the lender's balance sheet; Sold Growth equals the percentage change in mortgages sold by the originator. Regressions include both lender (reported) and borrower (not reported) control variables. Lender controls are from the Call Reports from the prior year; borrower controls are the average borrower and area income, loan size-to-income ratio, percent women and percent minority and percent minority in the area for loans made during the current year (from HMDA). Standard errors are clustered by bank. All regressions also include county*year fixed effects.

\begin{tabular}{|c|c|c|c|c|c|c|c|c|}
\hline \multirow{4}{*}{ Dependent Variable } & \multicolumn{4}{|c|}{ First-Stage } & \multirow{2}{*}{\multicolumn{2}{|c|}{ Retained Growth }} & \multirow{2}{*}{\multicolumn{2}{|c|}{ Sold Growth }} \\
\hline & \multicolumn{2}{|c|}{ Deposit Growth $_{\mathrm{t}}$} & \multicolumn{2}{|c|}{ Mortgage Growth } & & & & \\
\hline & & & OLS & IV & OLS & IV & OLS & IV \\
\hline & (1) & (2) & (3) & (4) & (5) & (6) & (7) & (8) \\
\hline \multirow[t]{2}{*}{ Share of Branches in Boom Counties } & $0.156^{* *}$ & - & - & - & - & - & - & - \\
\hline & $(1.97)$ & - & - & - & - & - & - & - \\
\hline \multirow[t]{2}{*}{ Growth in Shale Well Exposure $_{t}$} & - & $0.127^{* * *}$ & - & - & - & - & - & - \\
\hline & - & (3.10) & - & - & - & - & - & - \\
\hline \multirow[t]{2}{*}{ Deposit Growth $_{\mathrm{t}}$} & - & - & $0.637^{* * *}$ & $0.936^{*}$ & $0.575^{* * *}$ & $2.269 * * *$ & $0.434^{* * *}$ & 0.647 \\
\hline & - & - & $(5.37)$ & $(1.77)$ & (3.92) & (3.52) & $(4.35)$ & $(1.18)$ \\
\hline \multirow{2}{*}{ Log of Assets $\mathrm{t}_{\mathrm{t}-1}$} & 0.00294 & 0.00213 & -0.0139 & $-0.0148^{*}$ & -0.0123 & $-0.0207^{*}$ & $-0.0238 * *$ & $-0.0252^{* * *}$ \\
\hline & $(0.71)$ & $(0.54)$ & $(1.63)$ & $(1.76)$ & $(1.38)$ & (1.87) & (2.53) & (2.94) \\
\hline \multirow{2}{*}{ Deposits / Assets $\mathrm{t}_{\mathrm{t}-1}$} & -0.154 & $-0.139 *$ & 0.0245 & 0.0728 & -0.261 & -0.0931 & 0.114 & 0.16 \\
\hline & $(1.64)$ & $(1.67)$ & $(0.15)$ & $(0.37)$ & $(1.24)$ & $(0.33)$ & $(0.60)$ & $(0.79)$ \\
\hline \multirow[t]{2}{*}{ Cost of Deposits $\mathrm{t}_{\mathrm{t}-1}$} & -3.324 & -3.377 & 0.805 & 1.838 & -0.287 & 1.372 & -4.257 & -2.618 \\
\hline & (1.56) & (1.59) & $(0.35)$ & $(0.67)$ & $(0.09)$ & $(0.41)$ & $(1.01)$ & $(0.64)$ \\
\hline \multirow{2}{*}{ Liquid Assets / Assets $\mathrm{t}_{\mathrm{t}-1}$} & 0.0879 & 0.0692 & 0.0963 & 0.0685 & -0.0819 & -0.183 & $0.392 * *$ & 0.312 \\
\hline & $(0.75)$ & $(0.69)$ & $(0.69)$ & $(0.48)$ & $(0.43)$ & $(0.59)$ & $(2.18)$ & $(1.59)$ \\
\hline \multirow[t]{2}{*}{ Capital / Assets $_{\mathrm{t}-1}$} & 0.0272 & 0.0814 & $-1.471^{* *}$ & $-1.467 *$ & -0.3 & -0.263 & $-2.118^{* * *}$ & $-2.158^{* * *}$ \\
\hline & $(0.08)$ & $(0.24)$ & $(2.00)$ & $(1.89)$ & $(0.43)$ & $(0.25)$ & (2.99) & (3.00) \\
\hline \multirow[t]{2}{*}{ C\&I Loans / Asset $t_{t-1}$} & $0.273^{* * *}$ & $0.264^{* * *}$ & -0.0873 & -0.175 & -0.137 & -0.483 & 0.118 & 0.0259 \\
\hline & (3.60) & (3.50) & $(0.58)$ & $(0.78)$ & $(0.50)$ & $(1.58)$ & $(0.42)$ & $(0.08)$ \\
\hline \multirow[t]{2}{*}{ Mortgage Loans / Assets ${ }_{t-1}$} & 0.167 & 0.12 & -0.0567 & -0.112 & -0.0648 & -0.279 & 0.192 & 0.0985 \\
\hline & (1.19) & (1.18) & $(0.35)$ & $(0.63)$ & $(0.32)$ & $(0.85)$ & (1.19) & $(0.46)$ \\
\hline \multirow[t]{2}{*}{ Net Income / Assets $_{\mathrm{t}-1}$} & 1.027 & 1.104 & $3.822^{* *}$ & 3.48 & $6.419 *$ & $8.175^{*}$ & 2.35 & 2.225 \\
\hline & $(0.66)$ & $(0.75)$ & $(2.01)$ & $(1.55)$ & $(1.82)$ & (1.73) & $(0.87)$ & $(0.97)$ \\
\hline \multirow[t]{2}{*}{ Loan Commitments / Assets } & 0.0205 & 0.0186 & 0.0171 & 0.0109 & -0.0286 & -0.0559 & 0.009 & 0.000886 \\
\hline & $(1.46)$ & $(1.43)$ & $(0.71)$ & $(0.38)$ & $(0.74)$ & $(1.09)$ & $(0.27)$ & $(0.03)$ \\
\hline \multirow[t]{2}{*}{ Letters of Credits / Assets $\mathrm{t}_{\mathrm{t}-1}$} & -0.289 & -0.227 & 0.942 & 1.058 & 0.488 & 1.2 & $2.608^{* *}$ & $2.768^{* * *}$ \\
\hline & $(0.83)$ & $(0.66)$ & $(1.14)$ & $(1.29)$ & $(0.62)$ & $(1.47)$ & $(2.43)$ & (2.66) \\
\hline Borrower Controls & Yes & Yes & Yes & Yes & Yes & Yes & Yes & Yes \\
\hline County*Year FE & Yes & Yes & Yes & Yes & Yes & Yes & Yes & Yes \\
\hline Bank Clustered St Errors & Yes & Yes & Yes & Yes & Yes & Yes & Yes & Yes \\
\hline Observations & 92,144 & 92,144 & 92,144 & 92,069 & 71,034 & 70,910 & 49,427 & 49,221 \\
\hline R-squared & $9.9 \%$ & $11.6 \%$ & $2.8 \%$ & & $2.2 \%$ & & $2.4 \%$ & \\
\hline
\end{tabular}

T-stats reported in parentheses. ${ }^{* * *},{ }^{* *}$, and $*$ indicate significance at the $1 \%, 5 \%$ and $10 \%$ levels, respectively. 


\section{Table 3: Determinants of Entrance and Exit Decisions and Shale Booms}

This table estimates regressions of the determinants of a bank's shale boom exposure. The unit of observation is bank-year, and the dependent variable is a bank's shale boom exposure. Exposure Based on 2002 Branch Distribution is a bank's shale boom exposure based on holding its branch structure as of 2002. Application volume growth equals the percentage change in applications from the prior year, one and two year lags of this variable are included in the specifications. Columns (4) through (6) also include bank fixed effects, year fixed effects, and lender-specific control variables based on prior year call reports. Application Volume Growth measures are based on HMDA. Standard errors are clustered by bank.

$\underline{\text { Panel A }}$

Dependent Variable Share of Branches in Boom Counties

\begin{tabular}{cccccc}
\multicolumn{7}{c}{ Share of Branches in Boom Counties } \\
\hline$(1)$ & $(2)$ & $(3)$ & $(4)$ & $(5)$ & $(6)$ \\
$0.941^{* * *}$ & $0.945^{* * *}$ & $0.945^{* * *}$ & $0.912^{* * *}$ & $0.909 * * *$ & $0.909 * * *$ \\
$(92.47)$ & $(91.77)$ & $(91.40)$ & $(53.00)$ & $(50.88)$ & $(50.97)$ \\
0.0002 & - & 0.0001 & -0.0002 & - & -0.001 \\
$(0.34)$ & - & $(0.02)$ & $(0.26)$ & - & $(0.65)$ \\
- & 0.001 & 0.001 & - & 0.001 & 0.001 \\
- & $(1.64)$ & $(1.33)$ & - & $(1.09)$ & $(0.71)$ \\
& & & & & Yes \\
\hline Yes & Yes & Yes & Yes & Yes & Yes \\
- & - & - & Yes & Yes & Yes \\
9,049 & - & - & Yes & Yes & 6,948 \\
$92.5 \%$ & 8,482 & 8,322 & 7,549 & 7,065 & $96.9 \%$ \\
\hline
\end{tabular}

Year Effects

Bank Financial Controls

Bank Effects

Observations

R-squared

Growth in Shale Well Exposure

Dependent Variable

(4)

Exposure Based on 2002 Branch Distribution

\begin{tabular}{cccccc}
$0.961^{* * *}$ & $0.962^{* * *}$ & $0.961^{* * *}$ & $0.942^{* * *}$ & $0.941^{* * *}$ & $0.940 * * *$ \\
$(88.87)$ & $(87.78)$ & $(86.94)$ & $(57.76)$ & $(57.30)$ & $(57.05)$ \\
-0.001 & - & -0.001 & -0.001 & - & -0.002 \\
$(0.54)$ & - & $(0.70)$ & $(0.57)$ & - & $(0.95)$ \\
- & $0.0016^{*}$ & 0.001 & - & 0.002 & 0.001 \\
- & $(1.83)$ & $(1.24)$ & - & $(1.30)$ & $(0.61)$ \\
& & & & & \\
\hline Yes & Yes & Yes & Yes & Yes & Yes \\
- & - & - & Yes & Yes & Yes \\
- & - & - & Yes & Yes & Yes \\
9,049 & 8,482 & 8,322 & 7,549 & 7,065 & 6,948 \\
$93.7 \%$ & $93.9 \%$ & $94.0 \%$ & $96.8 \%$ & $97.0 \%$ & $97.1 \%$ \\
\hline
\end{tabular}

R-squared

T-stats reported in parentheses. ${ }^{* * *}, * *$, and * indicate significance at the $1 \%, 5 \%$ and $10 \%$ levels, respectively. 
Table 4: Effect of Deposit Supply Shock on Mortgage Lending: Reduced Form Regressions

This table reports reduced form regressions of the percentage change in mortgage originations by bank-county-year on measures of the exposure to shale-boom counties. Bank-county-years are excluded if the county actually experienced a shale boom. Mortgage Growth equals the percentage change in originations from the prior year; Retained Growth equals the percentage change in mortgages held on the lender's balance sheet; Sold Growth equals the percentage change in mortgages sold by the originator. Regressions include both lender (reported) and borrower (not reported) control variables. Lender controls are from the Call Reports from the prior year; borrower controls are the average borrower and area income, loan size-to-income ratio, percent women and percent minority and percent minority in the area for loans made during the current year (from HMDA). Standard errors are clustered by bank. All regressions also include county*year fixed effects.

Dependent Variable

Mortgage Growth $\quad$ Retained Growth

wth
Sold Growth

\begin{tabular}{|c|c|c|c|c|c|c|}
\hline & & & \\
\hline & $(1)$ & (2) & (3) & (4) & (5) & (6) \\
\hline \multirow[t]{2}{*}{ Share of Branches in Boom Counties } & $0.146^{* *}$ & - & $0.325^{* *}$ & - & 0.202 & - \\
\hline & $(2.17)$ & - & $(2.26)$ & - & $(1.26)$ & - \\
\hline \multirow[t]{2}{*}{ Growth in Shale Well Exposure $_{t}$} & - & $0.0533 * *$ & - & $0.223 * * *$ & - & 0.0674 \\
\hline & - & $(1.97)$ & - & (2.69) & - & $(1.37)$ \\
\hline \multirow[t]{2}{*}{ Log of Assets $\mathrm{t}_{\mathrm{t}-1}$} & -0.0121 & -0.0124 & -0.0096 & -0.0107 & $-0.0217 * *$ & $-0.0224 * *$ \\
\hline & $(1.45)$ & $(1.49)$ & $(1.11)$ & $(1.27)$ & $(2.10)$ & $(2.15)$ \\
\hline \multirow[t]{2}{*}{ Deposits / Assets $\mathrm{t}_{-1}$} & $(0.07)$ & $(0.07)$ & $(0.31)$ & $(0.29)$ & 0.06 & 0.07 \\
\hline & $(0.41)$ & $(0.39)$ & $(1.40)$ & $(1.32)$ & $(0.31)$ & $(0.33)$ \\
\hline \multirow[t]{2}{*}{ Cost of Deposits $\mathrm{t}_{-1}$} & $(1.27)$ & $(1.31)$ & $(0.88)$ & $(0.96)$ & $(6.30)$ & $(6.43)$ \\
\hline & $(0.43)$ & $(0.44)$ & $(0.24)$ & $(0.27)$ & $(1.37)$ & $(1.39)$ \\
\hline \multirow[t]{2}{*}{ Liquid Assets / Assets $_{\mathrm{t}-1}$} & 0.151 & 0.144 & -0.0596 & -0.0864 & $0.497 * *$ & $0.486 * *$ \\
\hline & $(1.08)$ & $(1.03)$ & $(0.31)$ & $(0.45)$ & $(2.58)$ & $(2.53)$ \\
\hline \multirow[t]{2}{*}{ Capital / Assets $_{\mathrm{t}-1}$} & $-1.442 * *$ & $-1.439 * *$ & -0.243 & -0.173 & $-1.987 * * *$ & $-1.990 * * *$ \\
\hline & $(2.20)$ & $(2.20)$ & $(0.39)$ & $(0.28)$ & (2.92) & (2.94) \\
\hline \multirow[t]{2}{*}{ C\&I Loans / Asset ${ }_{\mathrm{t}-1}$} & 0.081 & 0.0829 & -0.0453 & -0.0575 & 0.214 & 0.222 \\
\hline & $(0.54)$ & $(0.55)$ & $(0.16)$ & $(0.20)$ & $(0.70)$ & $(0.73)$ \\
\hline \multirow[t]{2}{*}{ Mortgage Loans / Assets $_{t-1}$} & 0.0445 & 0.031 & -0.0104 & -0.0697 & $0.289 *$ & 0.269 \\
\hline & $(0.29)$ & $(0.20)$ & $(0.05)$ & $(0.33)$ & $(1.73)$ & $(1.54)$ \\
\hline \multirow[t]{2}{*}{ Net Income / Assets $_{\mathrm{t}-1}$} & $4.441^{* *}$ & $4.517^{* *}$ & $5.606 *$ & $5.764 *$ & 2.474 & 2.593 \\
\hline & $(2.29)$ & $(2.33)$ & $(1.76)$ & $(1.78)$ & $(0.76)$ & $(0.80)$ \\
\hline \multirow[t]{2}{*}{ Loan Commitments / Assets $_{\mathrm{t}-1}$} & 0.0301 & 0.0292 & -0.0191 & -0.0222 & 0.0218 & 0.0194 \\
\hline & $(1.32)$ & $(1.28)$ & $(0.51)$ & $(0.59)$ & $(0.57)$ & $(0.51)$ \\
\hline \multirow[t]{2}{*}{ Letters of Credits / Assets $\mathrm{t}_{-1}$} & 0.787 & 0.768 & 0.402 & 0.452 & $2.525^{* *}$ & $2.497 * *$ \\
\hline & $(0.94)$ & $(0.92)$ & $(0.47)$ & $(0.53)$ & $(2.25)$ & $(2.23)$ \\
\hline Borrower Controls & Yes & Yes & Yes & Yes & Yes & Yes \\
\hline County*Year FE & Yes & Yes & Yes & Yes & Yes & Yes \\
\hline Bank Clustered St Errors & Yes & Yes & Yes & Yes & Yes & Yes \\
\hline Observations & 92,144 & 92,144 & 71,034 & 71,034 & 49,427 & 49,427 \\
\hline R-squared & $7.3 \%$ & $7.3 \%$ & $7.9 \%$ & $8.0 \%$ & $13.0 \%$ & $13.0 \%$ \\
\hline
\end{tabular}

T-stats reported in parentheses. ${ }^{* * *}, * *$, and $*$ indicate significance at the $1 \%, 5 \%$ and $10 \%$ levels, respectively. 


\section{Table 5: Reduced Form Robustness Tests}

This table estimates reduced form regressions of the percentage change in mortgage originations by bank-county-year using different robustness specifications. Bank-county-years are excluded if a county actually experienced a shale boom. Mortgage Growth equals the percentage change in originations from the prior year. Regressions include both lender (not reported) and borrower (not reported) control variables. Lender controls are from the Call Reports from the prior year; borrower controls are from HMDA. Columns (1) and (2) report the analysis of parallel trends of exposed and non-exposed banks. The Pre-Boom Indicator for Booming Banks is equal to 1 for booming banks in all the years leading to the boom exposure and zero

otherwise. The indicator is always equal to zero for banks that have never been exposed to the boom. Columns (3) and (4) report results based on counties that do not border any of the boom counties. In columns (5) and (6) we eliminate banks with negligible exposure to the boom, those with less than 2.5\% of affected branches. Columns (7) and (8) report results based on bankcounty-years where lender originated at least 15 mortgages in two subsequent years. Finally, in columns (9) and (10) we incorporate bank*county fixed effects. All regressions also include county-year fixed effects.

\begin{tabular}{|c|c|c|c|c|c|c|c|c|c|c|}
\hline & \multicolumn{10}{|c|}{ Dependent Variable: Mortgage Growth } \\
\hline & \multicolumn{2}{|c|}{ Parallel Trend Tests } & \multicolumn{2}{|c|}{$\begin{array}{l}\text { Excluding Counties } \\
\text { Neighboring Boom } \\
\text { Counties }\end{array}$} & \multicolumn{2}{|c|}{$\begin{array}{l}\text { Drop Banks with }<2.5 \% \\
\text { Exposure to the Boom }\end{array}$} & \multicolumn{2}{|c|}{$\begin{array}{c}\text { Bank-County } \\
\text { observations with at Least } \\
15 \text { Mortgages }\end{array}$} & \multicolumn{2}{|c|}{$\begin{array}{l}\text { Bank*County Fixed } \\
\text { Effects }\end{array}$} \\
\hline & (1) & (2) & (3) & (4) & (5) & (6) & (7) & (8) & (9) & (10) \\
\hline Share of Branches in Boom Counties & $\begin{array}{c}0.177^{* *} \\
(2.18)\end{array}$ & - & $\begin{array}{c}0.183^{* *} \\
(2.17)\end{array}$ & - & $\begin{array}{c}0.172 * * \\
(2.50)\end{array}$ & - & $\begin{array}{c}0.230 * * * \\
(3.22)\end{array}$ & $\begin{array}{l}- \\
-\end{array}$ & $\begin{array}{c}0.273 * * * \\
(5.89)\end{array}$ & $\begin{array}{l}- \\
-\end{array}$ \\
\hline Growth in Shale Well Exposure & $\begin{array}{l}- \\
-\end{array}$ & $\begin{array}{c}0.0535^{*} \\
(1.87)\end{array}$ & - & $\begin{array}{c}0.061 * * * \\
(2.00)\end{array}$ & - & $\begin{array}{c}0.0622 * * \\
(1.98)\end{array}$ & $\begin{array}{l}- \\
-\end{array}$ & $\begin{array}{c}0.0616^{* *} \\
(2.32)\end{array}$ & $\begin{array}{l}- \\
-\end{array}$ & $\begin{array}{c}0.110 * * * \\
(6.55)\end{array}$ \\
\hline Pre-Boom Indicator for Booming Banks & $\begin{array}{l}0.014 \\
(0.38) \\
\end{array}$ & $\begin{array}{l}0.014 \\
(0.36) \\
\end{array}$ & - & $\begin{array}{l}- \\
- \\
\end{array}$ & $\begin{array}{l}- \\
-\end{array}$ & $\begin{array}{l}- \\
- \\
\end{array}$ & - & $\begin{array}{l}- \\
- \\
\end{array}$ & - & $\begin{array}{l}- \\
- \\
\end{array}$ \\
\hline Borrower \& Lender Controls & Yes & Yes & Yes & Yes & Yes & Yes & Yes & Yes & Yes & Yes \\
\hline County*Year Fixed Effects & Yes & Yes & Yes & Yes & Yes & Yes & Yes & Yes & Yes & Yes \\
\hline Bank Clustered St Errors & Yes & Yes & Yes & Yes & Yes & Yes & Yes & Yes & Yes & Yes \\
\hline Bank*County Fixed Effects & - & - & - & - & - & - & - & - & Yes & Yes \\
\hline $\begin{array}{l}\text { Observations } \\
\text { R-squared }\end{array}$ & $\begin{array}{c}92,144 \\
7.3 \%\end{array}$ & $\begin{array}{c}92,144 \\
7.3 \%\end{array}$ & $\begin{array}{c}62,189 \\
7.0 \%\end{array}$ & $\begin{array}{c}62,189 \\
7.1 \%\end{array}$ & $\begin{array}{c}81,788 \\
7,6 \%\end{array}$ & $\begin{array}{c}81,788 \\
7,6 \%\end{array}$ & $\begin{array}{l}30,365 \\
19,7 \%\end{array}$ & $\begin{array}{l}30,365 \\
197 \%\end{array}$ & $\begin{array}{l}92,144 \\
16,5 \%\end{array}$ & $\begin{array}{l}92,144 \\
16,5 \%\end{array}$ \\
\hline
\end{tabular}

T-stats reported in parentheses. $* * *, * *$, and * indicate significance at the $1 \%, 5 \%$ and $10 \%$ levels, respectively. 


\section{Table 6: Deposit Supply Shock and Mortgage Lending:}

\section{The Effect of Local Lenders}

This table reports reduced form regressions of the percentage change in mortgage originations by bank-county-year. Bank-county-years are excluded if the county actually experienced a shale boom. Local Lenders are those with a branch in the county (distant lenders originate mortgages without a branch in the county). Mortgage Growth equals the percentage change in originations from the prior year. Regressions include both lender (reported) and borrower (not reported) control variables. Lender controls are from the Cal Reports from the prior year; borrower controls are the average borrower and area income, loan size-to-income ratio, percent women and percent minority and percent minority in the area for loans made during the current year (from HMDA). Standard errors are clustered by bank. All regressions also include county*year fixed effects.

\begin{tabular}{|c|c|c|c|c|}
\hline \multirow[t]{3}{*}{ Dependent Variable } & \multicolumn{4}{|c|}{ Mortgage Growth } \\
\hline & \multicolumn{2}{|c|}{ All Lenders } & \multicolumn{2}{|c|}{ Local Lenders Only } \\
\hline & (1) & (2) & (3) & (4) \\
\hline Local-Lender Indicator & $\begin{array}{l}0.008 \\
(0.48)\end{array}$ & $\begin{array}{l}0.008 \\
(0.54)\end{array}$ & $\begin{array}{l}- \\
-\end{array}$ & $\begin{array}{l}- \\
-\end{array}$ \\
\hline Share of Branches in Boom Counties & $\begin{array}{l}0.100 \\
(1.30)\end{array}$ & $\begin{array}{l}- \\
-\end{array}$ & $\begin{array}{c}0.234^{* *} \\
(2.35)\end{array}$ & \\
\hline Growth in Shale Well Exposure & $\begin{array}{l}- \\
-\end{array}$ & $\begin{array}{l}0.035 \\
(1.00)\end{array}$ & $\begin{array}{l}- \\
-\end{array}$ & $\begin{array}{c}0.103^{* *} \\
(2.03)\end{array}$ \\
\hline $\begin{array}{c}\text { Share of Branches in Boom Counties * } \\
\text { Local-Lender Indicator }\end{array}$ & $\begin{array}{c}0.231^{* *} \\
(2.17)\end{array}$ & $\begin{array}{l}- \\
-\end{array}$ & $\begin{array}{l}- \\
-\end{array}$ & $\begin{array}{l}- \\
-\end{array}$ \\
\hline $\begin{array}{l}\text { Growth in Shale Well Exposure } \\
\text { Local-Lender Indicator }\end{array}$ & $\begin{array}{l}- \\
-\end{array}$ & $\begin{array}{c}0.126^{* *} \\
(1.99)\end{array}$ & $\begin{array}{l}- \\
-\end{array}$ & $\begin{array}{l}- \\
-\end{array}$ \\
\hline Log of Assets $t_{t-1}$ & $\begin{array}{l}-0.012 \\
(1.52)\end{array}$ & $\begin{array}{l}-0.012 \\
(1.54)\end{array}$ & $\begin{array}{l}0.009 \\
(1.03)\end{array}$ & $\begin{array}{l}0.009 \\
(1.05)\end{array}$ \\
\hline Deposits / Assets $\mathrm{t}_{\mathrm{t}-1}$ & $\begin{array}{l}-0.124 \\
(0.69)\end{array}$ & $\begin{array}{l}-0.121 \\
(0.66)\end{array}$ & $\begin{array}{c}0.404^{* * *} \\
(3.91)\end{array}$ & $\begin{array}{c}0.402 * * * \\
(3.90)\end{array}$ \\
\hline Cost of Deposits $\mathrm{t}_{\mathrm{t}-1}$ & $\begin{array}{l}-2.552 \\
(0.85)\end{array}$ & $\begin{array}{c}-2.555 \\
(0.85)\end{array}$ & $\begin{array}{l}-1.360 \\
(0.25)\end{array}$ & $\begin{array}{l}-1.360 \\
(0.25)\end{array}$ \\
\hline Liquid Assets / Assets $\mathrm{t}_{\mathrm{t}-1}$ & $\begin{array}{l}0.116 \\
(0.80)\end{array}$ & $\begin{array}{l}0.112 \\
(0.78)\end{array}$ & $\begin{array}{c}0.260^{* *} \\
(2.19)\end{array}$ & $\begin{array}{c}0.261^{* *} \\
(2.19)\end{array}$ \\
\hline Capital / Assets t-1 $_{1}$ & $\begin{array}{c}-1.432 * * \\
(2.15)\end{array}$ & $\begin{array}{c}-1.431^{* *} \\
(2.15)\end{array}$ & $\begin{array}{l}-0.320 \\
(0.50)\end{array}$ & $\begin{array}{l}-0.318 \\
(0.49)\end{array}$ \\
\hline C\&I Loans / Asset ${ }_{t-1}$ & $\begin{array}{l}0.019 \\
(0.12)\end{array}$ & $\begin{array}{l}0.022 \\
(0.14)\end{array}$ & $\begin{array}{l}0.185 \\
(1.16)\end{array}$ & $\begin{array}{l}0.190 \\
(1.19)\end{array}$ \\
\hline Mortgage Loans / Assets $\mathrm{t}_{\mathrm{t}-1}$ & $\begin{array}{l}0.085 \\
(0.56)\end{array}$ & $\begin{array}{l}0.077 \\
(0.49)\end{array}$ & $\begin{array}{l}0.053 \\
(0.34)\end{array}$ & $\begin{array}{l}0.050 \\
(0.32)\end{array}$ \\
\hline Net Income / Assets $_{t-1}$ & $\begin{array}{l}3.872 * \\
(1.85)\end{array}$ & $\begin{array}{l}3.938^{*} \\
(1.87)\end{array}$ & $\begin{array}{l}2.103 \\
(0.82)\end{array}$ & $\begin{array}{l}2.155 \\
(0.84)\end{array}$ \\
\hline Loan Commitments / Assets $_{\mathrm{t}-1}$ & $\begin{array}{l}0.026 \\
(1.16)\end{array}$ & $\begin{array}{l}0.025 \\
(1.13)\end{array}$ & $\begin{array}{l}-0.101 \\
(0.73)\end{array}$ & $\begin{array}{l}-0.103 \\
(0.75)\end{array}$ \\
\hline Letters of Credits / Assets $\mathrm{s}_{\mathrm{t}-1}$ & $\begin{array}{l}0.654 \\
(0.75) \\
\end{array}$ & $\begin{array}{l}0.628 \\
(0.72) \\
\end{array}$ & $\begin{array}{r}-0.261 \\
(0.38) \\
\end{array}$ & $\begin{array}{r}-0.304 \\
(0.44) \\
\end{array}$ \\
\hline Borrower Controls & Yes & Yes & Yes & Yes \\
\hline County*Year FE & Yes & Yes & Yes & Yes \\
\hline Bank Clustered St Errors & Yes & Yes & Yes & Yes \\
\hline Observations & 93,739 & 93,739 & 22,316 & 22,316 \\
\hline R-squared & $7.3 \%$ & $7.2 \%$ & $20.2 \%$ & $20.2 \%$ \\
\hline
\end{tabular}

T-stats reported in parentheses. ${ }^{* * *},{ }^{* *}$, and $*$ indicate significance at the $1 \%, 5 \%$ and $10 \%$ levels, respectively. 


\section{Table 7: Effect of Deposit Supply Shock by Mortgage Type}

This table reports reduced form regressions of the percentage change in mortgage originations by bank-county-year, broken out by mortgages for home purchase, home-equity lines, and refinancing. Bank-county-years are excluded if the county actually experienced shale boom. Regressions include both lender and borrower control variables (not reported). Lender controls are from the Call Reports from the prior year; borrower controls are the average borrower and area income, loan size-to-income ratio, percent women and percent minority and percent minority in the area for loans made during the current year (from HMDA). Standard errors are clustered by bank. All regressions also include county*year fixed effects.

\begin{tabular}{|c|c|c|c|}
\hline Dependent Variable & & Mortgage Growth & \\
\hline & $\begin{array}{c}\text { Home Purchase } \\
\text { Mortgages }\end{array}$ & Home Equity Loans & Refinancings \\
\hline & $(1)$ & $(2)$ & (3) \\
\hline \multicolumn{4}{|l|}{ Panel A } \\
\hline 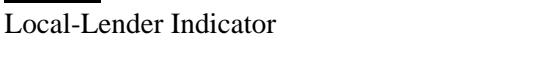 & $\begin{array}{c}-0.0350^{* *} \\
(-2.554)\end{array}$ & $\begin{array}{l}-0.0372 \\
(-1.206)\end{array}$ & $\begin{array}{l}-0.00673 \\
(-0.338)\end{array}$ \\
\hline Share of Branches in Boom Counties & $\begin{array}{l}0.0626 \\
(0.89)\end{array}$ & $\begin{array}{l}-0.172 \\
(-0.978)\end{array}$ & $\begin{array}{l}0.188^{*} \\
(1.91)\end{array}$ \\
\hline $\begin{array}{c}\text { Share of Branches in Boom Counties * } \\
\text { Local-Lender Indicator }\end{array}$ & $\begin{array}{c}0.245^{* *} \\
(2.44) \\
\end{array}$ & $\begin{array}{c}0.592^{* * *} \\
(2.74) \\
\end{array}$ & $\begin{array}{l}0.0642 \\
(0.50)\end{array}$ \\
\hline Borrower \& Lender controls & Yes & Yes & Yes \\
\hline County*Year FE & Yes & Yes & Yes \\
\hline Bank Clustered St Errors & Yes & Yes & Yes \\
\hline Observations & 64,860 & 34,839 & 66,237 \\
\hline $\mathrm{R}^{2}$ & $9 \%$ & $16 \%$ & $15 \%$ \\
\hline z-statistic for: $(1)==(2)$ & & $(1.457)$ & \\
\hline z-statistic for: $(2)==(3)$ & & (2.099) & \\
\hline z-statistic for: $(1)==(3)$ & & $(1.106)$ & \\
\hline \multicolumn{4}{|l|}{ Panel B } \\
\hline$\overline{\text { Local-Lender indicator }}$ & $\begin{array}{c}-0.0348 * * \\
(-2.564)\end{array}$ & $\begin{array}{l}-0.0345 \\
(-1.140)\end{array}$ & $\begin{array}{c}-0.00692 \\
(-0.355)\end{array}$ \\
\hline Growth in Shale Well Exposure & $\begin{array}{l}0.034 \\
(1.07)\end{array}$ & $\begin{array}{c}-0.083 \\
(-1.533)\end{array}$ & $\begin{array}{l}0.0483 \\
(1.16)\end{array}$ \\
\hline $\begin{array}{l}\text { Growth in Shale Well Exposure * } \\
\text { Local-Lender Indicator }\end{array}$ & $\begin{array}{c}0.154^{* *} \\
(2.33)\end{array}$ & $\begin{array}{l}0.305^{* * *} \\
(2.87)\end{array}$ & $\begin{array}{c}0.0328 \\
(0.45)\end{array}$ \\
\hline Borrower \& Lender controls & Yes & Yes & Yes \\
\hline County*Year FE & Yes & Yes & Yes \\
\hline Bank Clustered St Errors & Yes & Yes & Yes \\
\hline Observations & 64,860 & 34,839 & 66,237 \\
\hline $\mathrm{R}^{2}$ & $9 \%$ & $16 \%$ & $15 \%$ \\
\hline z-statistic for: $(1)==(2)$ & & $(1.208)$ & \\
\hline z-statistic for: $(2)==(3)$ & & (2.108) & \\
\hline z-statistic for: (1) $==(3)$ & & $(1.227)$ & \\
\hline
\end{tabular}

T-stats reported in parentheses. ${ }^{* * *}, * *$, and $*$ indicate significance at the $1 \%, 5 \%$ and $10 \%$ levels, respectively. 
Table 8: Effect of Deposit Supply Shock on Mortgage Lending:

All Counties for Local Lenders Only

This table reports reduced form regressions of the percentage change in mortgage originations by bank-county-year. In this table, we include bank-county-years for counties that actually experienced shale booms in columns (1) and (2). Columns (3) and (4) include only non-boom counties; these repeat the results from Table 6 and are included to ease comparison across samples. Mortgage Growth equals the percentage change in originations from the prior year. Regressions include both lender (reported) and borrower (not reported) control variables. Lender controls are from the Call Reports from the prior year; borrower controls are the average borrower and area income, loan size-to-income ratio, percent women and percent minority and percent minority in the area for loans made during the current year (from HMDA). Standard errors are clustered by bank. All regressions also include county*year fixed effects.

Dependent Variable

\begin{tabular}{llll} 
& & \multicolumn{2}{c}{ Mortgage Growth } \\
All Counties & & \multicolumn{2}{c}{ Non-Boom Only } \\
\hline$(1)$ & $(2)$ & (3)
\end{tabular}

Boom-County Indicator

Share of Branches in Boom Counties

Growth in Shale Well Exposure

Share of Branches in Boom Counties * Boom-County Indicator Growth in Shale Well Exposure Boom-County Indicator

Log of Assets

Deposits / Assets $\mathrm{t}_{\mathrm{-}-1}$

Cost of Deposits $\mathrm{t}_{\mathrm{t}-1}$

Liquid Assets / Assets

Capital / Assets $_{t-1}$

C\&I Loans / Asset $_{t-1}$

Mortgage Loans / Assets $_{\mathrm{t}-1}$

Net Income / Assets

Loan Commitments / Assets $_{\mathrm{t}-1}$

Letters of Credits / Assets

Borrower Controls

County*Year FE

Bank Clustered St Errors

Coefficient absorbed by the county*year fixed effects

\begin{tabular}{|c|c|c|c|}
\hline $0.286^{* * *}$ & - & $0.234^{* *}$ & - \\
\hline$(2.81)$ & - & $(2.35)$ & - \\
\hline - & $0.118^{* *}$ & - & $0.103^{* *}$ \\
\hline - & $(2.28)$ & - & $(2.03)$ \\
\hline$-0.272^{* *}$ & - & - & - \\
\hline$(2.52)$ & - & - & - \\
\hline- & $-0.11^{* *}$ & - & - \\
\hline - & $(1.98)$ & - & - \\
\hline $\begin{array}{c}0.00922 \\
(1.20)\end{array}$ & $\begin{array}{c}0.00939 \\
(1.21)\end{array}$ & $\begin{array}{l}0.009 \\
(1.03)\end{array}$ & $\begin{array}{l}0.009 \\
(1.05)\end{array}$ \\
\hline $0.390 * * *$ & $0.388 * * *$ & $0.404 * * *$ & $0.402 * * *$ \\
\hline (3.92) & $(3.90)$ & $(3.91)$ & (3.90) \\
\hline-0.818 & -0.827 & -1.360 & -1.360 \\
\hline$(0.16)$ & $(0.16)$ & $(0.25)$ & $(0.25)$ \\
\hline $0.343^{* * *}$ & $0.343^{* * * *}$ & $0.260^{* *}$ & $0.261^{* * *}$ \\
\hline (2.95) & $(2.94)$ & (2.19) & $(2.19)$ \\
\hline-0.21 & -0.208 & -0.320 & -0.318 \\
\hline$(0.33)$ & $(0.32)$ & $(0.50)$ & $(0.49)$ \\
\hline 0.248 & $0.255^{*}$ & 0.185 & 0.190 \\
\hline (1.63) & (1.67) & (1.16) & (1.19) \\
\hline 0.114 & 0.111 & 0.053 & 0.050 \\
\hline$(0.77)$ & $(0.74)$ & $(0.34)$ & $(0.32)$ \\
\hline 1.987 & 2.043 & 2.103 & 2.155 \\
\hline$(0.83)$ & $(0.85)$ & $(0.82)$ & $(0.84)$ \\
\hline-0.117 & -0.119 & -0.101 & -0.103 \\
\hline (1.11) & (1.13) & $(0.73)$ & $(0.75)$ \\
\hline-0.0932 & -0.141 & -0.261 & -0.304 \\
\hline$(0.14)$ & $(0.22)$ & $(0.38)$ & $(0.44)$ \\
\hline Yes & Yes & Yes & Yes \\
\hline Yes & Yes & Yes & Yes \\
\hline Yes & Yes & Yes & Yes \\
\hline 27,217 & 27,217 & 22,329 & 22,329 \\
\hline 0.196 & 0.196 & 0.202 & 0.201 \\
\hline
\end{tabular}

0.196

0.202

0.201

Observations

T-stats reported in parentheses. ${ }^{* * *}, * *$, and $*$ indicate significance at the $1 \%, 5 \%$ and $10 \%$ levels, respectively. 


\section{Table 9: Effect of Deposit Supply Shock on Mortgage Lending:}

\section{Unserved Credit Demand and Financial Constraints}

This table reports reduced form regressions of the percentage change in mortgage originations by bank-county-year. This table includes only lenders with a branch in a given county. Bank-county-years are excluded if the county actually experienced a shale boom. Lagged Mortgage Approval Rate equals the bank's approval rate for mortgages made from the prior county-year. Mortgage Growth equals the percentage change in originations from the prior year; Lagged Bank Capital Ratio equals the book value of capital / total assets for the lender from the prior year. Regressions include both lender and borrower (not reported)

control variables. Lender controls are from the Call Reports from the prior year; borrower controls are the average borrower and area income, loan size-to-income ratio, percent women and percent minority and percent minority in the area for loans made during the current year (from HMDA). Standard errors are clustered by bank. All regressions also include county*year fixed effects.

\begin{tabular}{|c|c|c|c|c|c|c|}
\hline \multirow[t]{3}{*}{ Dependent Variable } & \multicolumn{6}{|c|}{ Mortgage Growth } \\
\hline & \multicolumn{3}{|c|}{ Share of Branches in Boom County } & \multicolumn{3}{|c|}{ Growth in Shale Well Exposure } \\
\hline & $(1)$ & $(2)$ & (3) & (4) & (5) & (6) \\
\hline Share of Branches in Boom Counties & $\begin{array}{l}0.888 \\
(1.34)\end{array}$ & $\begin{array}{l}-0.176 \\
(0.45)\end{array}$ & $\begin{array}{l}0.417 \\
(0.58)\end{array}$ & - & - & - \\
\hline Share of Branches in Boom Counties * & $-0.799 *$ & & $-0.731^{* *}$ & - & - & - \\
\hline Lagged Mortgage Approval Rate & $(1.68)$ & & $(2.01)$ & - & - & - \\
\hline Share of Branches in Boom County * & - & $3.582^{* * *}$ & $4.132 *$ & - & - & - \\
\hline Lagged Bank Capital Ratio & - & $(2.92)$ & $(1.85)$ & - & - & - \\
\hline Growth in Shale Well Exposure & - & - & - & 0.423 & -0.104 & 0.155 \\
\hline & - & - & - & $(1.17)$ & $(0.49)$ & $(0.46)$ \\
\hline Growth in Shale Well Exposure & - & - & - & $-0.409 *$ & - & $-0.389 * *$ \\
\hline Lagged Mortgage Approval Rate & - & - & - & $(1.86)$ & - & $(1.97)$ \\
\hline Growth in Shale Well Exposure & - & - & - & - & $2.131^{* *}$ & $4.61^{* *}$ \\
\hline Lagged Bank Capital Ratio & - & - & - & - & $(1.97)$ & $(2.13)$ \\
\hline Lender Controls & Yes & Yes & Yes & Yes & Yes & Yes \\
\hline Borrower Controls & Yes & Yes & Yes & Yes & Yes & Yes \\
\hline County*Year FE & Yes & Yes & Yes & Yes & Yes & Yes \\
\hline Bank Clustered St Errors & Yes & Yes & Yes & Yes & Yes & Yes \\
\hline $\begin{array}{l}\text { Lagged Mortgage Approval Rate \& Lagged } \\
\text { Bank Capital }\end{array}$ & Yes & Yes & Yes & Yes & Yes & Yes \\
\hline Observations & 22,316 & 22,316 & 22,316 & 22,316 & 22,316 & 22,316 \\
\hline R-squared & $21.30 \%$ & $20.20 \%$ & $21.34 \%$ & $21.30 \%$ & $20.20 \%$ & $21.35 \%$ \\
\hline
\end{tabular}

T-stats reported in parentheses. ${ }^{* * *}, * *$, and $*$ indicate significance at the $1 \%, 5 \%$ and $10 \%$ levels, respectively. 